\title{
Antimycobacterial Activities of Ruthenium(II) Complexes of Hydroxyl Flavone Hydrazones
}

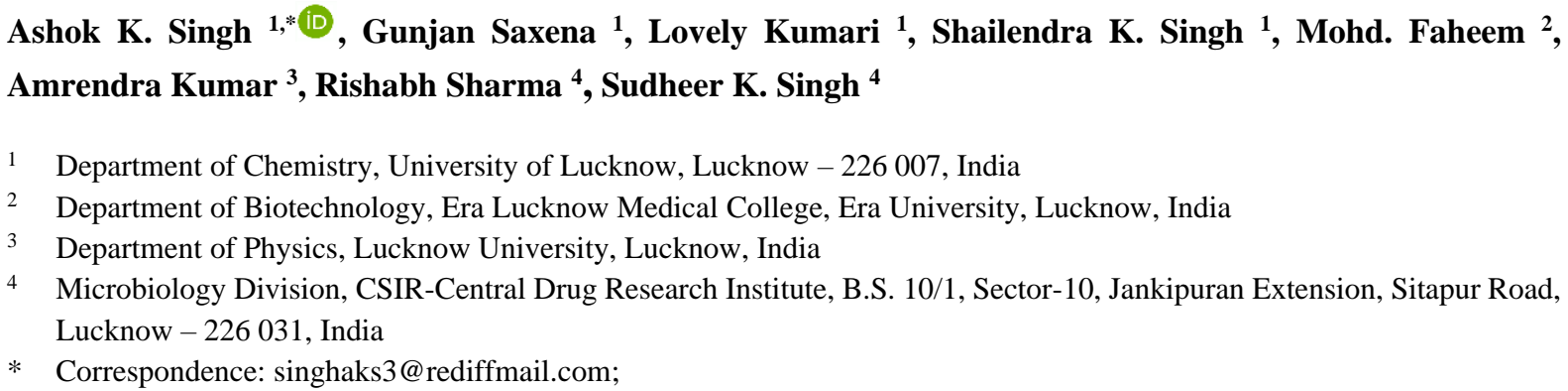

Received: 4.09.2020; Revised: 27.09.2020; Accepted: 29.09.2020; Published: 2.10.2020

\begin{abstract}
The Ru(II) complexes of hydrazine derivatives of different 3-hydroxy 4-substituted flavones was synthesized to assess their biological activity. The ligand 2, 4 dinitrophenyl hydrazones of 3hydroxy 4'-substituted flavones [where 4'-substituents are - $\mathrm{OCH}_{3}(\mathrm{HL} 1),-\mathrm{NO}_{2}(\mathrm{HL} 2), \mathrm{NMe}_{2}(\mathrm{HL} 3), \mathrm{Cl}$ (HL4), $\mathrm{OCH}_{2} \mathrm{Ph}$ (HL5)] were successfully coordinated with $\mathrm{Ru}(\mathrm{phen})_{2} \mathrm{Cl}_{2}$ which consists of the formula, $\quad\left[\mathrm{Ru}(\text { phen })_{2}(\mathrm{HL} 1)\right] \mathrm{Cl}_{2} .2 .5 \mathrm{H}_{2} \mathrm{O} \quad(\mathrm{M} 1 \mathrm{R}), \quad\left[\mathrm{Ru}(\text { phen })_{2}(\mathrm{HL} 2)\right] \mathrm{Cl}_{2}(\mathrm{M} 2 \mathrm{R})$, $\left[\mathrm{Ru}(\text { phen })_{2}(\mathrm{HL} 3)\right] \mathrm{Cl}_{2}(\mathrm{M} 3 \mathrm{R}), \quad\left[\mathrm{Ru}(\text { phen })_{2}(\mathrm{HL} 4)\right] \mathrm{Cl}_{2} .1 .5 \mathrm{H}_{2} \mathrm{O} \quad$ (M4R), $\quad\left[\mathrm{Ru}(\text { phen })_{2}(\mathrm{HL} 5)\right] \mathrm{Cl}_{2} .1 .5 \mathrm{H}_{2} \mathrm{O}$ (M5R). All the synthesized complexes were characterized by elemental analysis, IR, ${ }^{1} \mathrm{H}-\mathrm{NMR}$, UVVis, and ESI-MS spectroscopic techniques. The geometry optimization of all complexes was carried by using Gaussian-09. All compounds were studied for antimycobacterial activity using Resazurin microtiter plate assay (REMA) followed by colony-forming unit (CFU) count. The metal complexes showed promising activity against $M$. smegmatis $\mathrm{mc}^{2}$. The DNA interaction of the complexes was also studied. These studies suggest that hydrazine derivatives of 3-hydroxy 4-substituted flavones and their $\mathrm{Ru}$ (II) complexes can be good candidates for antimycobacterial drug development studies.
\end{abstract}

Keywords: Hydroxyl flavone hydrazones; chelate; DNA interaction; antimycobacterial; Resazurinmicrotiter.

(c) 2020 by the authors. This article is an open-access article distributed under the terms and conditions of the Creative
Commons Attribution (CC BY) license (https://creativecommons.org/licenses/by/4.0/).

\section{Introduction}

Mycobacteria are a type of microorganism that causes tuberculosis and leprosy and additionally induces typical mycobacterial infections. Many medicines are available, but most of them are resistant to these infections. Despite many perspectives, it still remains a worldwide threat. Due to several drug-resistant strains, tuberculosis will once again be a major threat against mycobacterial diseases. Therefore, several new complexes of $\mathrm{Cu}$ and $\mathrm{Zn}$ against mycobacteria have been reported [1]. Isonicotinic acid hydrazide was widely used in the treatment of Mycobacterium avium known as isoniazid. 2, 4-dinitrophenylhydrazine (DNPH) is an analog of hydrazine and has recently gained considerable interest in the chemistry of hydrazine complexes due to their potential medicinal values [2]. In the present study, we synthesized 3-hydroxy 4-substituted flavones and their 2, 4-DNPH derivatives and explored the possibility of nitro containing flavonol hydrazine complexes that show antimicrobial 
activity. Ruthenium occupies a prominent position among various metals that are currently being investigated for their anticancerous and antimycobacterial activities [3, 4]. The biologically important ruthenium polypyridyl complexes have been well known for being coordinatively saturated as well as for being substitutionally inert and display unique redox properties $[5,6]$. Their structural diversity and chemical and redox properties provide a unique opportunity for designing molecules with biological activity [7]. Flavones, either natural or synthetic, are well known, and their attraction as synthetic targets is due to the various biological activities, which are of significant current interest [8]. The ruthenium complexes of 2, 4-dinitrophenyl hydrazones of flavonols have been attempted during the present study in order to enhance the activities and have led to a new line of investigation that focuses on the potential of ruthenium-based inorganic medicine. In this respect, we have synthesized five new ruthenium Flavonol Hydrazone complexes. The ruthenium complexes of 2, 4-dinitrophenyl hydrazones of flavonols synthesized to investigate antimycobacterial activities and DNA interactions studies. Their activities have been found to be highly dependent on the nature of the metal ion and the donor atoms of the ligands, since different ligands show different biological properties, though they vary slightly in their molecular structures.

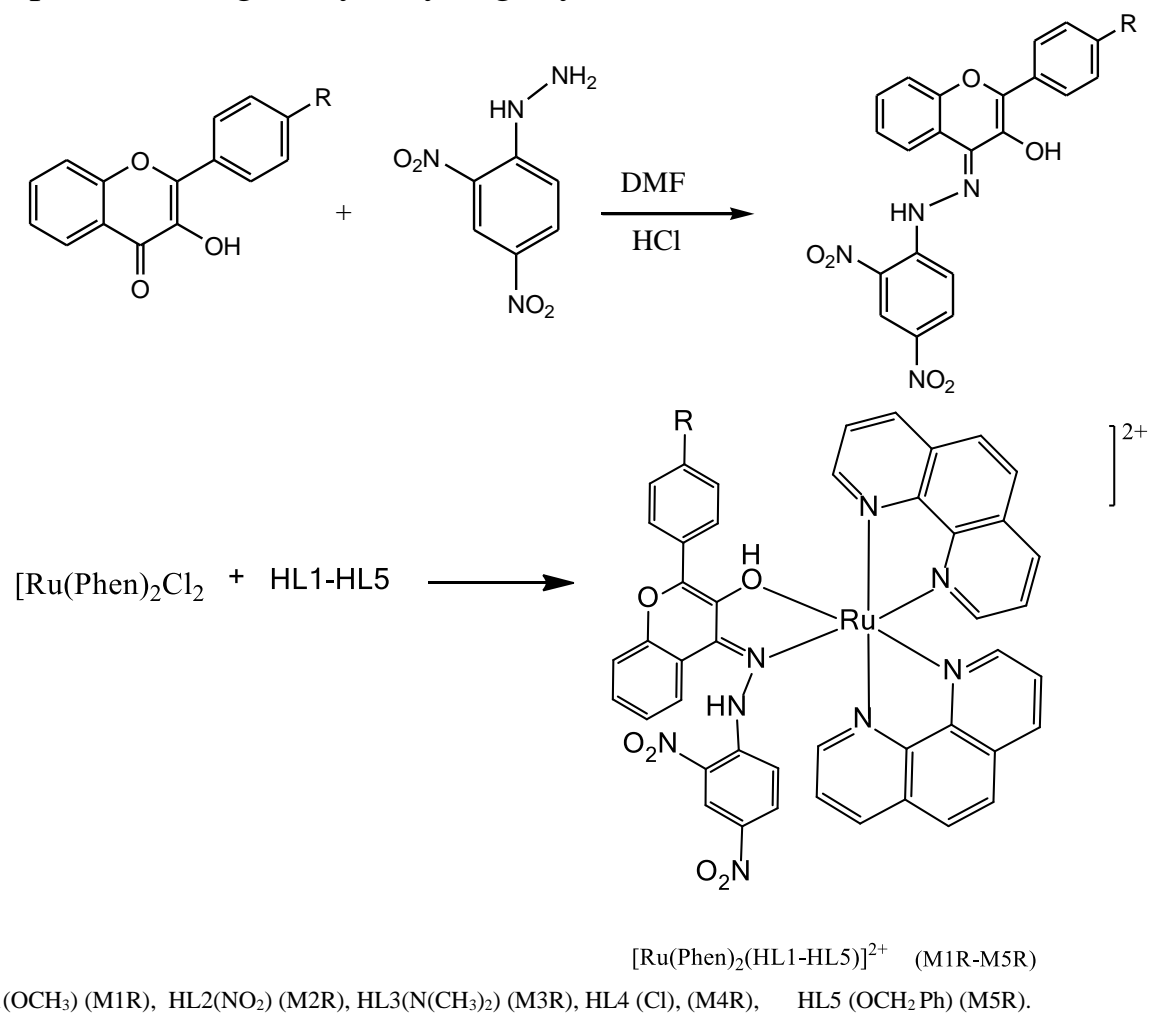

$\mathrm{R}=\mathrm{HL} 1\left(\mathrm{OCH}_{3}\right)(\mathrm{M} 1 \mathrm{R}), \mathrm{HL} 2\left(\mathrm{NO}_{2}\right)(\mathrm{M} 2 \mathrm{R}), \mathrm{HL} 3\left(\mathrm{~N}\left(\mathrm{CH}_{3}\right)_{2}\right)(\mathrm{M} 3 \mathrm{R}), \mathrm{HL} 4(\mathrm{Cl}),(\mathrm{M} 4 \mathrm{R}), \quad \mathrm{HL} 5\left(\mathrm{OCH}_{2} \mathrm{Ph}\right)(\mathrm{M} 5 \mathrm{R})$

Scheme 1. Chemical structures of Ligands (HL1-HL5) and ruthenium(II) metal complexes (M1R M5R).

\section{Materials and Methods}

All the chemicals used during the present study were of analytical grade. Solvents were purified and dried according to standard procedures. Elemental analysis was performed on Exeter analytical Inc. "Model CE-440 CHNS analyzer'. Electronic absorption spectra were recorded on Labtronic LT-2900 UV-Vis Spectrophotometer. Melting points were recorded on the capillary melting point apparatus and are uncorrected. FTIR spectra were recorded on Perkin-Elmer AC-1 spectrometer. ${ }^{1} \mathrm{H}-\mathrm{NMR}$ spectra were run on Bruker Avance DPX $500 \mathrm{MHz}$ in DMSO-d6, TMS was used as an internal standard. ESI-mass spectra were recorded on JEOL SX 102/DA-6000. The DFT calculation was carried out using the Gaussian- 09 program 
package with B3LYP [9]. The comparison has been made with other related complexes, and they show high structural consistency [10].

\subsection{Synthesis.}

Synthesis of (Z)-4-(2-(2,4-dinitrophenyl)hydrazono)-2-(4-substituted phenyl)-4Hchromen-3-ol (HL1-HL5). The 3-hydroxy 4- substituted flavones were synthesized by using Aldol condensation. Further, 3-hydroxy 4-substituted flavone hydrazones were synthesized as given in the literature [11]. The methanolic solution $(20 \mathrm{ml})$ of 3-hydroxy 4-substituted flavone (1 mmol, $268 \mathrm{mg} . / 283 \mathrm{mg} . / 281 \mathrm{mg} . / 0.272 \mathrm{mg} . / 0.344 \mathrm{mg}$. for Sub:- $\mathrm{OCH}_{3}(\mathrm{HL} 1) /-\mathrm{NO}_{2}(\mathrm{HL} 2) /$ $-\mathrm{N}\left(\mathrm{CH}_{3}\right)_{2}(\mathrm{HL} 3) /-\mathrm{Cl}(\mathrm{HL} 4) /-\mathrm{OCH}_{2} \mathrm{C}_{6} \mathrm{H}_{5}$ (HL5)) respectively. The solution was stirred at 50$60^{\circ} \mathrm{C}$ and further added 2, 4 dinitrophenyl hydrazine(DNP) in $5 \mathrm{ml}$ of dimethylformamide contained in $50 \mathrm{ml}$ round bottom flask [12,13]. It was refluxed for 30min and then cooled at $25^{\circ} \mathrm{C}$ and added a few drops of concentrated hydrochloric acid( $\left.\mathrm{HCl}\right)$ was added and allowed to stand at room temperature. The solid product was filtered and washed with a $2 \mathrm{~N} \mathrm{HCl}$ solution and recrystallized in ethanol /THF.

(Z)-4-(2-(2,4-dinitrophenyl)hydrazono)-2-(4-methoxyphenyl)-4H-chromen-3-ol (HL1). Colour: Orange, Yield: $311 \mathrm{mg}, 72 \%, \mathrm{Mp} .154^{\circ} \mathrm{C}$. FT- IR $\left(\mathrm{KBr}, \mathrm{cm}^{-1}\right): v=3325 v(\mathrm{NH}), 3600$ $(\mathrm{OH}), 1518$ (s, C=C), 1618 (s, C=N), $1494\left(\mathrm{Ar}-\mathrm{NO}_{2}\right), 1318\left(\mathrm{Ar}-\mathrm{NO}_{2}\right)$; 1H NMR (500 MHz, DMSO- $\left.d 6,25^{\circ} \mathrm{C}, \mathrm{TMS}\right) \delta(\mathrm{ppm}): 11.42(\mathrm{~s}, 1 \mathrm{H}, \mathrm{NH}), 09.01(\mathrm{~s}, 1 \mathrm{H}, \mathrm{OH}), 7.0-9.0(\mathrm{Ar}-\mathrm{H}), 1.56$ (s, 3H, C-OMe); For C22H16N4O7: Anal. Cal.: C 58.93, H 3.60, N 12.95, Found: C 58.66, H 3.93, N 12.26\%. UV-Vis, (DMF, $\lambda \max (\mathrm{nm}) \varepsilon \max$ ): 256(400), 300(500), 360(1100).

(Z)-4-(2-(2,4-dinitrophenyl)hydrazono)-2-(4-nitrophenyl)-4H-chromen-3-ol

(HL2). Colour: Orange; Yield: 305mg , 69\% . m.p. $290^{\circ} \mathrm{C}$. FT- IR $\left(\mathrm{KBr}, \mathrm{cm}^{-1}\right): v=3312(\mathrm{NH}), 3400$ $(\mathrm{OH}), 1519(\mathrm{C}=\mathrm{C}), 1617(\mathrm{C}=\mathrm{N}), 1434$ (Ar-NO2), 1332 (Ar-NO2); ${ }^{1} \mathrm{H}$ NMR (DMSO-d6, 500 $\left.\mathrm{MHz}, 25^{\circ} \mathrm{C}, \mathrm{TMS}\right) \delta(\mathrm{ppm}): 11.81(\mathrm{~s}, 1 \mathrm{H}, \mathrm{NH}), 10.98$ ( s, 1H, OH), 7.89 -8.89 (m, Ar-H); For C21H13N5O8: Anal. Cal.: C 54.42, H 2.81, N 15.12\%; Found: C 54.66, H 3.93, N 15.36\%; UV-Vis (DMF, $\lambda \max (\mathrm{nm}) \varepsilon \max ): 222(6300), 243(29600), 290(6300)$.

(Z)-4-(2-(2,4-dinitrophenyl)hydrazono)-2-(4-dimethylaminophenyl)-4H-chromen-3ol (HL3). Colour: Orange; Yield: $271 \mathrm{mg}, 63 \%$; m.p: $150^{\circ} \mathrm{C}$; FT- IR $\left(\mathrm{KBr}, \mathrm{cm}^{-1}\right): v=3280(\mathrm{NH})$, $3419(\mathrm{OH}), 1503(\mathrm{C}=\mathrm{C}), 1618(\mathrm{C}=\mathrm{N}), 1459\left(\mathrm{Ar}-\mathrm{NO}_{2}\right), 1321\left(\mathrm{Ar}-\mathrm{NO}_{2}\right) ;{ }^{1} \mathrm{H}$ NMR (DMSO-d6, $\left.500 \mathrm{MHz}, 25^{\circ} \mathrm{C}, \mathrm{TMS}\right) \delta(\mathrm{ppm}): 12.91(\mathrm{~s}, 1 \mathrm{H}, \mathrm{NH}), 10.86(\mathrm{OH}), 6.79-8.87(\mathrm{~m}, \mathrm{Ar}-\mathrm{H}), 1.56(\mathrm{~s}$, 6H, CH3); For C23H19N5O6: Anal. Cal.: C 59.87, H 4.15, N 15.18; Found: C 59.56, H 4.33, N 15.36. UV-Vis, (DMF, $\lambda \max (\mathrm{nm}) \varepsilon \max )$ : 270(300), 340(500), 450(900).

(Z)-4-(2-(2,4-dinitrophenyl)hydrazone)-2-(4-chloroyphenyl)-4H-chromen-3-ol (HL4). Colour: Orange; Yield: $313 \mathrm{mg}, 72 \%$; m.p: $155^{\circ} \mathrm{C}$. FT- IR $\left(\mathrm{KBr}, \mathrm{cm}^{-1}\right): v=3325 v(\mathrm{NH}), 3450$ $(\mathrm{OH}), 1518(\mathrm{C}=\mathrm{C}), 1608(\mathrm{C}=\mathrm{N}), 1097(\mathrm{C}-\mathrm{Cl}), 1492\left(\mathrm{Ar}-\mathrm{NO}_{2}\right), 1318$ (Ar-NO2); 1H NMR (DMSO-d6, $\left.500 \mathrm{MHz}, 25^{\circ} \mathrm{C}, \mathrm{TMS}\right) \delta(\mathrm{ppm}): 11.57$ (s, 1H, NH), $10.37(\mathrm{OH}), 6.80-8.87$ (m, ArH); For C21H13O6N4Cl: Anal. Cal.: C 55.70, H 2.89, N 12.38; Found: C 55.56, H 2.53, N 12.36. UV-Vis, (DMF, $\lambda \max (\mathrm{nm}) \mathrm{\varepsilon max}$ ): 260(300), 340(500), 450(900).

(Z)-4-(2-(2,4-dinitrophenyl)hydrazone)-2-(4-benzyloxyphenyl)-4H-chromen-3-ol (HL5). Colour: Orange; Yield: 346, 68\%; m.p: $110^{\circ} \mathrm{C}$; FT- IR $\left(\mathrm{KBr}, \mathrm{cm}^{-1}\right): v=3366 v(\mathrm{NH}), 3480$ $(\mathrm{OH}), 1519(\mathrm{C}=\mathrm{C}), 1618(\mathrm{C}=\mathrm{N}), 1494\left(\mathrm{Ar}-\mathrm{NO}_{2}\right), 1322\left(\mathrm{Ar}-\mathrm{NO}_{2}\right)$; ${ }^{1} \mathrm{H}-\mathrm{NMR}(\mathrm{DMSO}-d 6,500$ $\left.\mathrm{MHz}, 25^{\circ} \mathrm{C}, \mathrm{TMS}\right) \delta(\mathrm{ppm}): 11.46(\mathrm{~s}, 1 \mathrm{H}, \mathrm{NH}), 10.63(\mathrm{OH}), 7.13-8.35$ (m, Ar-H), 3.48 (s, 2H, $\mathrm{OCH}_{2} \mathrm{C}_{6} \mathrm{H}_{5}$ ); For C28 H20 N4 O7: Anal. Cal.:C 64.12, H 3.85, N 10.68\%; Found: C 64.52, H 3.64, N 10.36\%; UV-Vis,(DMF, $\lambda \max$ (nm) عmax): 280(1500), 455(5500). 


\subsection{Synthesis of ruthenium(II) metal complexes.}

For the synthesis of $\mathrm{Ru}(\mathrm{Phen})_{2} \mathrm{Cl}_{2}$, taken $1 \mathrm{~g}$ of ruthenium trichloride hydrated, $1.4 \mathrm{~g}$ of $\mathrm{LiCl}$ and $1.5 \mathrm{~g}$ of 1,10 phenanthroline in a $9 \mathrm{ml}$ of DMF in a round bottom flask and the solution was refluxed for $8 \mathrm{~h}$ under the nitrogen atmosphere $[14,15]$. Reduced the volume of the solution and was allowed to cool. $10 \mathrm{ml}$ of acetone was added to it and kept overnight for 24h. Afterward, it was filtered and recrystallized. Taken (1mmole, $448 \mathrm{mg} / 463 \mathrm{mg} / 461 \mathrm{mg} /$ $552 \mathrm{mg} / 524 \mathrm{mg})$ for $\left(-\mathrm{OCH}_{3} /-\mathrm{NO}_{2} /-\mathrm{N}\left(\mathrm{CH}_{3}\right)_{2} /-\mathrm{Cl} /-\mathrm{OCH}_{2} \mathrm{C}_{6} \mathrm{H}_{5}\right)$ respectively, of 3-hydroxy 4-substituted flavone hydrazones with $1 \mathrm{mmol}\left(532 \mathrm{mg}\right.$.) of $\mathrm{Ru}$ (phen) ${ }_{2} \mathrm{Cl}_{2}$ or $\mathrm{RuCl}_{3} .3 \mathrm{H}_{2} \mathrm{O}(262$ $\mathrm{mg}$ ) in $30 \mathrm{ml}$ of THF and added one drop of triethylamine in the solution. It was carried out in warm conditions with stirring for $24 \mathrm{~h}$ and subsequently refluxed for $8 \mathrm{~h}$. After refluxing, the volume was reduced, then the precipitate was filtered and recrystallized in THF.

[Ru(phen) $\left.{ }_{2}(\mathbf{H L 1})\right] \mathbf{C l}_{2} .2 .5 \mathbf{H}_{2} \mathrm{O}$ (M1R). Colour: Brown; Yield: 515mg, 52\%; m. p : $340^{\circ} \mathrm{C}$; FT- IR $\left(\mathrm{KBr}, \mathrm{cm}^{-1}\right): v=3330(\mathrm{NH}), 3370(\mathrm{OH}), 1518(\mathrm{C}=\mathrm{C}), 1610(\mathrm{C}=\mathrm{N}), 1423(\mathrm{Ar}-\mathrm{NO} 2)$, 1325 (Ar-NO ${ }_{2}$ ); ${ }^{1} \mathrm{H}-\mathrm{NMR}$ (DMSO-d6, $\left.500 \mathrm{MHz}, 25^{\circ} \mathrm{C}, \mathrm{TMS}\right) \delta(\mathrm{ppm}): 12.71(\mathrm{NH}), 11.53$ $(\mathrm{S}, 1 \mathrm{H}, \mathrm{OH}), 6.88-8.85$ (m, Ar-H), 1.21 (OMe); For RuC46 H36 N8 O9.5 Cl2: Anal. Cal.: C 53.91, H 3.54, N 10.93, Cl 6.92\%; Found: C 53.46, H 3.93, N 11.26, Cl 7.25\%; (ESI/MS) m/z : calcd for 1024 (1023); UV-Vis, (DMF, $\left.10^{-3} \mathrm{M}, \lambda \max (\mathrm{nm}) \varepsilon \max \right)$ : 230(100), 278(900), 360(300), 460(100).

[Ru(phen) $\left.{ }_{2}(\mathbf{H L 2})\right] \mathrm{Cl}_{2}$ (M2R). Colour: Brown; Yield: 536mg, 55\%; m. p: $230^{\circ} \mathrm{C}$. FT- IR (KBr, cm $\left.{ }^{-1}\right): v=3319(\mathrm{NH}), 3377(\mathrm{OH}), 1520(\mathrm{C}=\mathrm{C}), 1613(\mathrm{C}=\mathrm{N}), 1422\left(\mathrm{Ar}_{-} \mathrm{NO}_{2}\right)$, 1337 (Ar-NO 2 ); ${ }^{1} \mathrm{H}-\mathrm{NMR}$ (DMSO-d6, $500 \mathrm{MHz}, 25^{\circ} \mathrm{C}$, TMS) $\delta(\mathrm{ppm}): 10.84$ (s, NH), 10.27 (s, OH), 7.86-8.90 (m, Ar-H); For RuC45 H28 N9 O8 Cl2: Anal. Cal.: C 54.33, H 2.84, N 12.67\%; Found C 53.93, H 3.04, N 12.46\%; ESI/MS: 994 (993); UV-Vis, (DMF, 10-3M, $\lambda \max (\mathrm{nm})$ عmax): 252(8900), 339(2800), 431(5900).

[Ru(phen) $)_{2}(\mathbf{H L 3}) \mathbf{C l}_{\mathbf{2}}$ (M3R). Colour: Brown; Yield: $423 \mathrm{mg}, 44 \%$; m. p: $360^{\circ} \mathrm{C}$; FT- IR $\left(\mathrm{KBr}, \mathrm{cm}^{-1}\right): v=3274(\mathrm{NH}), 3409(\mathrm{OH}), 1503(\mathrm{C}=\mathrm{C}), 1609(\mathrm{C}=\mathrm{N}), 1413\left(\mathrm{Ar}^{-N_{2}}\right), 1320(\mathrm{Ar}-$ $\mathrm{NO}_{2}$ ); ${ }^{1} \mathrm{H}-\mathrm{NMR}$ (DMSO-d6, $\left.500 \mathrm{MHz}, 25^{\circ} \mathrm{C}, \mathrm{TMS}\right) \delta(\mathrm{ppm}): \delta 11.54$ (s, 1H, NH), 10.73 (s, $\mathrm{OH}$ ), 6.77-8.87 (m, Ar-H) , 3.03 (s, 6H,CH3), 2.59 (s, 6H, CH3); For Ru C47 H34 N9 O6 Cl2: Anal Calcd for : C 56.86, H 3.45, N 12.70\%; Found C 56.55, H 3.78, N 12.47\%; ESI/MS: 992 (993); UV-Vis,(DMF, 10-3 M $\lambda \max$ (nm) عmax): 230(600), 260(2000), 450(0.55), 500(sh).

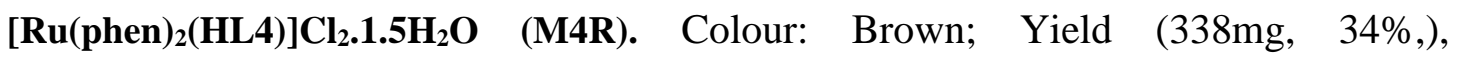
m. p. > 360 ${ }^{\circ}$. FT- IR (KBr, cm $\left.{ }^{-1}\right)$; v: $3374(\mathrm{NH}), 3319(\mathrm{OH}), 1514(\mathrm{C}=\mathrm{C}), 1604(\mathrm{C}=\mathrm{N}), 1482$ (Ar-NO2), 1318 (Ar-NO2). ${ }^{1} \mathrm{H}-\mathrm{NMR}$ (DMSO-d6, 500MHz, 25 $\left.{ }^{\circ} \mathrm{C}, \mathrm{TMS}\right) \delta(\mathrm{ppm}): \delta 11.48$ (S, 1H, NH), 10.28 (s, OH), 7.49-8.26 (m, Ar-H); For Ru C45 H31 N8 O7.5 Cl3: Anal. Cal.: C 53.45, H 3.09, N 11.08\%, Found C 53.86, H 3.32, N 11.67\%. ESI/MS 1010 (1010). UV-Vis, (DMF, 10-3M, $\lambda \max$ (nm) عmax): 260(500), 280(1500), 320(600), 450(2500).

$\left.[\mathrm{Ru} \text { (phen) })_{2}(\mathrm{HL} 5)\right] \mathrm{Cl}_{2} .1 .5 \mathrm{H}_{2} \mathrm{O}$ (M5R): Colour: Brown; Yield: 501mg, 47\%; m.p:257 ${ }^{\circ} \mathrm{C}$; FT- IR $\left(\mathrm{KBr}, \mathrm{cm}^{-1}\right): v=3440(\mathrm{NH}), 3364(\mathrm{OH}), 1519(\mathrm{C}=\mathrm{C}), 1618(\mathrm{C}=\mathrm{N}), 1481(\mathrm{Ar}-\mathrm{NO} 2), 1318$ (Ar$\left.\mathrm{NO}_{2}\right) ;{ }^{1} \mathrm{H}-\mathrm{NMR}$ (DMSO-d6, 500MHz, 25oC, TMS) $\delta(\mathrm{ppm}): 1.81-1.88$ (b, 1H, NH), 8.23 (s, $\mathrm{OH})$, 6.87-7.97 (m, Ar-H), 5.15 (d, 2H, OCH2); For Ru C52 H38 N8 O7 Cl2: Anal. Cal: C 57.68, H 3.54, N 10.35\%; Found: C 57.23, H 3.26, N 10.58\%; ESI/MS: 1082 (1081); UV-Vis (DMF, 10-3M, $\lambda \max$ (nm) عmax): 250(1300), 280(1900), 400(sh,200), 500(100). 


\subsection{Biological assay.}

\subsubsection{Antimycobacterial drug susceptibility testing.}

The antimycobacterial drug susceptibility testing (DST) was performed using the Resazurinmicrotiter plate assay with glycerol as a carbon source [16]. The details are as provided: the M. Smegmatis $\mathrm{mc}^{2} \log$ phase culture was diluted using Middlebrook $7 \mathrm{H} 9$ broth (Difco) to give an OD600 of 0.05 , and $100 \mu 1$ of it was taken in the microtiter plate. Also, 100 $\mu \mathrm{l}$ of MB7H9 medium with glycerol as a carbon source was used. The compound concentration was initially adjusted to $50 \mu \mathrm{m}$. The sterility control, growth control, and solvent controls were also included. All experiments were performed in duplicate. The plates were sealed properly and incubated for $48 \mathrm{~h}$, at $37^{\circ} \mathrm{C}$. At the end of incubation, $30 \mu \mathrm{l}$ of resazurin stock $(0.02 \% \mathrm{w} / \mathrm{v})$ was added, mixed thoroughly, and their absorbance was measured at $573 \mathrm{~nm}$ using a continuous wavelength absorbance plate reader (Multiskan Spectrum, Thermo Scientific). Afterward, plates were incubated for $4 \mathrm{~h}$ to measure the second absorbance and subsequently kept for $\mathrm{o} / \mathrm{n}$ at $37^{\circ} \mathrm{C}$. The difference in absorbance between $4 \mathrm{~h}$ and $0 \mathrm{~h}$ was used to plot growth inhibition with respect to control. The plates were also visually scored after o/n incubation for color change from blue to pink. The visual observation method was used to confirm the growth inhibition with compounds showing no color change from blue to pink after o/n incubation were selected for minimum inhibitory concentration (MIC) determinations. The MIC determinations were carried by serially diluting compounds to a final concentration of 50,25 , $12.5,6.25$, and $3.125 \mu \mathrm{M}$ in the culture medium. For this, the plating of initial as well as final culture was performed after serial dilution on Luria Bertani(LB) agar plates supplemented with glycerol $(1 \% \mathrm{v} / \mathrm{v})$ and Tween-80 $(0.05 \% \mathrm{v} / \mathrm{v})$. The plates were incubated for 2 days at $37^{\circ} \mathrm{C}$, and CFU count was performed to calculate $\%$ growth inhibition. The MIC was calculated as the concentration of the compound, which caused a greater than $99 \%$ reduction in CFU count.

\subsubsection{DNA ruthenium complex interaction studies.}

The interaction studies of complexes with DNA were performed by taking different concentrations of complexes $(2,4,6,8$, and $10 \mu \mathrm{m})$ and measuring its absorption spectra. Also, different concentrations of DNA were incubated with a fixed concentration of complexes, and their absorption spectra were measured. Similarly, concentrations of metal complexes were varied $(2,4,6,8$, and $10 \mu \mathrm{m})$ at a fixed $(200 \mathrm{mg})$ DNA concentration. Absorption spectra were recorded using a UV-visible spectrophotometer (Multiskan Spectrum, Thermo Scientific) using a $1 \mathrm{~cm}$ path length quartz cuvette at $250 \mathrm{C}$. For gel mobility shift assay, fixed DNA (200 $\mathrm{mg}$ ) concentrations were incubated with three different concentrations $(2.5,5.0$, and $7.5 \mu \mathrm{m})$ of the metal complex, and DNA electrophoretic mobility was analyzed in $1 \%$ agarose gel (TAE). The agarose gel was visualized UV-Visible transilluminator (UVP).

\section{Results and Discussion}

The structure and coordination number of the complexes were unambiguously characterized by analytical studies, IR, ${ }^{1} \mathrm{H}-\mathrm{NMR}$, ESI-MS, UV-Vis, and the structure was optimized using Gaussian 09. Complexes were found to be soluble in DMF and DMSO, but partially soluble in acetone and chloroform. IR and ${ }^{1} \mathrm{H}-\mathrm{NMR}$ agree with the formula assigned to the spectral characteristics. 


\subsection{FT-IR spectral studies.}

The IR spectral data of the ligands and complexes suggested the formation of the complexes as given in Scheme-1. The IR spectrum of flavones is assigned to $1605-1693 \mathrm{~cm}$ ${ }^{1}$ and $3420-3435 \mathrm{~cm}^{-1}$ for $v(\mathrm{C}=\mathrm{O})$ and $v(\mathrm{OH})$ groups, respectively. Furthermore, in the IR spectrum of Flavonol Hydrazones, a characteristic peak of $v(\mathrm{C}=\mathrm{O})$ group disappeared, which were assigned to the formation of the new ligands. Further, new peaks were observed at 1608$1618 \mathrm{~cm}^{-1}$ and $3280-3325 \mathrm{~cm}^{-1}$ of $v(\mathrm{C}=\mathrm{N})$ and $v(\mathrm{NH})$ vibrations, respectively, which supports the formation of 2, 4 DNP derivatives of flavone as ligands, which was further supported by ${ }^{1} \mathrm{H}-\mathrm{NMR}$ [17]. In the spectrum of the metal complexes (M1R-M5R), major shifting of phenolic $\mathrm{OH}$ group and $(\mathrm{C}=\mathrm{N})$ group of ligands shifted to the lower energy of 10 to $15 \mathrm{~cm}^{-1}$, indicates that it has coordinated with the $\mathrm{Ru}(\mathrm{II})$ ion in complexes. Additionally, the observations of peaks at $3274-3374 \mathrm{~cm}^{-1}$ in the spectrum of metal complexes were assigned to the uncoordinated $\mathrm{NH}$ group, confirmed the coordination to the Ligands. Though there are four coordinating sites in 2, 4 DNP derivatives of flavone, it coordinated preferentially through $\mathrm{OH}$ and $\mathrm{C}=\mathrm{N}$, as to maintain their coordinating nature. Additionally, the band at $1482-1413 \mathrm{~cm}^{-1}$ and $1335-1318$ $\mathrm{cm}^{-1}$, shows a lower shift of 10-40 $\mathrm{cm}^{-1}$, supports the binding through $\mathrm{N}$ and ' $\mathrm{O}$ ' respectively. Furthermore, the appearance of the band at 556-500 $\mathrm{cm}^{-1}$ region supports the binding of $v(\mathrm{Ru}-$ O). However, in M1R-M5R there was observed the appearance of two peaks i.e. $650-476 \mathrm{~cm}^{-}$ ${ }^{1}$ of $v(\mathrm{M}-\mathrm{N})$ of phenanthroline, which supports the cis configuration of the complexes [18].

\section{$3.2{ }^{1}$ H NMR studies.}

For further structural support, ${ }^{1} \mathrm{H}-\mathrm{NMR}$ spectra of the Ligands and complexes were recorded in DMSO-d6. In the spectra of the complexes M1R-M5R, NH proton did not deprotonate, but there was a slight shifting of $\mathrm{NH}$ proton to lower $\delta$ ppm value, so it appears that coordination took place via $\mathrm{C}=\mathrm{N}$. Further, there was a shifting of $\mathrm{OH}$ protons, which was observed in the range 9.25-11.53 $\mathrm{\delta pm}$ as compared to their corresponding ligands, which appeared in the range 9.01-10.98. In the spectra of the complexes, peaks observed at 6.77- 8.90 $\delta$ ppm were assigned to aromatic protons that were shifted to lower $\delta$ ppm value supports the complexation has been taken place [19].In all complexes, there is a downfield shifting of the $\mathrm{NH}$ and $\mathrm{OH}$ proton, this is due to the strong intermolecular hydrogen bonding interactions present in the hydrazones and the solvent. This is seen in M5R, where there is a shift in NH (1.81-1.88 broad) and $\mathrm{OH}(8.23)$ proton. This is due to deshielding occurs due to making and breaking Hydrogen bonding in the solvent. Further, integration ratios corresponding to aromatic protons were assigned to hydrazine derivatives of 3-hydroxy 4-substituted flavone, and 1, 10 phenanthroline were in agreement with molecular formulae as assigned. Additionally, the presence of 1,10 phenanthroline groups in complexes was supported by peaks observed at

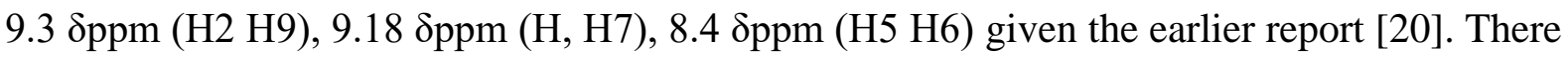
are signals at $7.90(\mathrm{~d}), 8.35(\mathrm{~d})$, and 8.90 (s) $\delta$ ppm indicates the presence of aromatic hydrogens at the position $3 \mathrm{H}, 5 \mathrm{H}$, and $6 \mathrm{H}$, respectively. Though mixed peaks due to polypyridyl and aromatic groups complicated the spectra, yet they were analyzed in accordance with the reported assignments [21]. Due to very poor solubility, the ${ }^{13} \mathrm{C}$ NMR is not possible.

\subsection{Mass spectral studies.}

The binding of $\mathrm{Ru}(\mathrm{II})$ metal ion with substituted 2, 4 dinitrophenyl hydrazine derivatives of 3-hydroxy 4-substituted flavone was investigated by mass spectroscopy. In the 
mass spectrum base peak observed at 1024, (calcd. $\mathrm{m} / \mathrm{z}$ at 1024 , found 1023) arises due to [Ru(phen) $\left.)_{2}(\mathrm{HL} 1)\right] \mathrm{Cl}_{2} 2.5 \mathrm{H}_{2} \mathrm{O}$, further the loss of chloride ion and water outside the coordination sphere with a base peak at 908 of $\left[\mathrm{Ru}(\text { phen })_{2}(\mathrm{HL} 1)\right]^{2+}$ calcd. at $\mathrm{m} / \mathrm{z} 908$. Similarly, the peaks of $\left[\mathrm{Ru}(\mathrm{phen})_{2}(\mathrm{HL} 2)\right] \mathrm{Cl}_{2}$ at $994, \mathrm{~m} / \mathrm{z}$ at 993 and with loss of $2 \mathrm{Cl}^{-}$at 923 were found at $\mathrm{m} / \mathrm{z} 922$. Furthermore, all complexes shows similar type of fragmentation pattern as, in $\left[\mathrm{Ru}(\text { phen })_{2}(\mathrm{HL} 3)\right] \mathrm{Cl}_{2}$ at $992, \mathrm{~m} / \mathrm{z}$ at $991 ;\left[\mathrm{Ru}(\text { phen })_{2}(\mathrm{HL} 3)\right]^{2+}$ at $921, \mathrm{~m} / \mathrm{z}$ at 920 with loss of $2 \mathrm{Cl}^{-}$ions. In $\left[\mathrm{Ru}(\text { phen })_{2}(\mathrm{HL} 4)\right] \mathrm{Cl}_{2} 1.5 \mathrm{H}_{2} \mathrm{O}$ at $1010, \mathrm{~m} / \mathrm{z}$ at 1010 , and $\left[\mathrm{Ru}(\text { phen })_{2}(\mathrm{HL} 4)\right]^{2+}$ at $912, \mathrm{~m} / \mathrm{z}$ at 911 with loss of $2 \mathrm{Cl}^{-}$and $1.5 \mathrm{H} 2 \mathrm{O}$. For other complexes $\left[\mathrm{Ru}(\mathrm{phen})_{2}(\mathrm{HL} 5)\right] \mathrm{Cl}_{2}$ $1.5 \mathrm{H}_{2} \mathrm{O}$ at $1081, \mathrm{~m} / \mathrm{z}$ at 1080 and $\left[\mathrm{Ru}(\text { phen })_{2}(\mathrm{HL} 5)\right]^{2+}$ at $984, \mathrm{~m} / \mathrm{z}$ at 985 with loss of $2 \mathrm{Cl}^{-}$and $1.5 \mathrm{H}_{2} \mathrm{O}$. All the above fragmentation patterns are in accordance with the other spectroscopic (IR and ${ }^{1} \mathrm{H}-\mathrm{NMR}$ ).

\subsection{Electronic absorbtion studies.}

The electronic spectral data for the 2, 4 DNP derivatives of different 3-hydroxy 4substituted flavone and their metal complexes in DMF $\left(10^{-3} \mathrm{M}\right)$ in the range 200-600 nm shown in S. Fig4. The ligand 3-hydroxy 4-substituted flavone based intense absorptions were observed at 254 and $270 \mathrm{~nm}$ assigned to $\pi-\pi^{*} \& \mathrm{n}-\pi^{*}$ transitions within the ligands. Further, in 4-methoxy flavonol peak observed at $432 \mathrm{~nm}$ was perturbed in their 2,4 DNP derivatives, which supports the condensation of the 2, 4 DNP with 3-hydroxy 4-methoxy flavone. However, the Peaks observed in the range 455-450 in 3-hydroxy 4-substituted flavones, which support the condensation of DNP with the ketonic group of the flavones. However, there is a longer wavelength shift in HL3, and HL4 ligands show nonbonding transitions. In the spectra of all metal complexes band observed at $431-525 \mathrm{~nm}$, which is characteristic of $\mathrm{Ru}(\mathrm{II})$ ion as reported earlier [22].

Table 1. Optimized geometrical parameters for the Ru(II) complexes (bond length $(\AA)$ and bond angle $\left({ }^{\circ}\right)$.

\begin{tabular}{c|c|c|c|c|c} 
PARAMETER & M1R & M2R & M3R & M4R & M5R \\
\hline Ru-N1 & 2.130 & 2.157 & 2.147 & 2.156 & 2.151 \\
\hline Ru-N2 & 2.139 & 2.143 & 2.130 & 2.142 & 2.140 \\
\hline Ru-N3 & 2.128 & 2.129 & 2.132 & 2.129 & 2.130 \\
\hline Ru-N4 & 2.078 & 2.079 & 2.080 & 2.080 & 2.080 \\
\hline Ru-N5 & 2.117 & 2.111 & 2.111 & 2.111 & 2.111 \\
\hline Ru-O & 2.214 & 2.203 & 2.147 & 2.300 & 2.196 \\
\hline N1-Ru-O & 74.99 & 74.00 & 74.52 & 74.18 & 74.34 \\
\hline N2-Ru-N3 & 78.08 & 78.38 & 78.25 & 78.27 & 78.28 \\
\hline N4-Ru-N5 & 79.14 & 79.36 & 79.29 & 79.33 & 79.32 \\
\hline N1-Ru-N3 & 172.75 & 168.88 & 169.35 & 168.87 & 168.97 \\
\hline N1-Ru-N2 & 98.75 & 93.24 & 93.18 & 93.22 & 93.14 \\
\hline N1-Ru-N4 & 98.36 & 100.88 & 169.36 & 100.83 & 100.54 \\
\hline N1-Ru-N5 & 87.63 & 95.08 & 94.88 & 94.94 & 94.85
\end{tabular}

All the complexes are mononuclear with the band in the region from 200 to $525 \mathrm{~nm}$. However, from the electronic spectra, the oxidation state of $\mathrm{Ru}$ cannot be concluded but supported by the ${ }^{1} \mathrm{H}-\mathrm{NMR}$ spectrum of all complexes. 


\subsection{Computational studies.}

\subsubsection{Geometry optimization.}

The theoretical DFT calculations were performed for metal complexes (M1R-M5R) in the gas phase using B3LYP and LANL2DZ basis set[23]. The selected interatomic distances and bond angle for all complexes are collected in Table1. As follows from this table, the calculated bond distances between $\mathrm{Ru}-\mathrm{N}$ and $\mathrm{Ru}-\mathrm{O}$ of flavanolhydrazones are 2.157-1.130 and 2.142- 2.130, respectively. In a similar way, the $\mathrm{Ru}-\mathrm{N}$ bond distances of 1,10 phenanthroline ligand are 2.142-2.111. In all the complexes, the bond angles are also in the range. The results showed that the computed structural parameter given in Table 1 are reliable with the Single X-ray data of related structures [24].

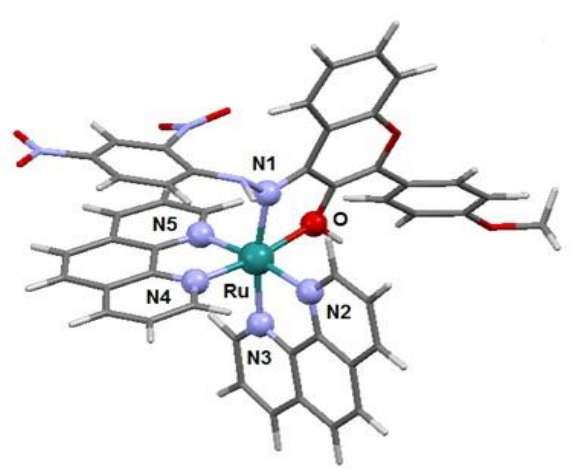

M1R

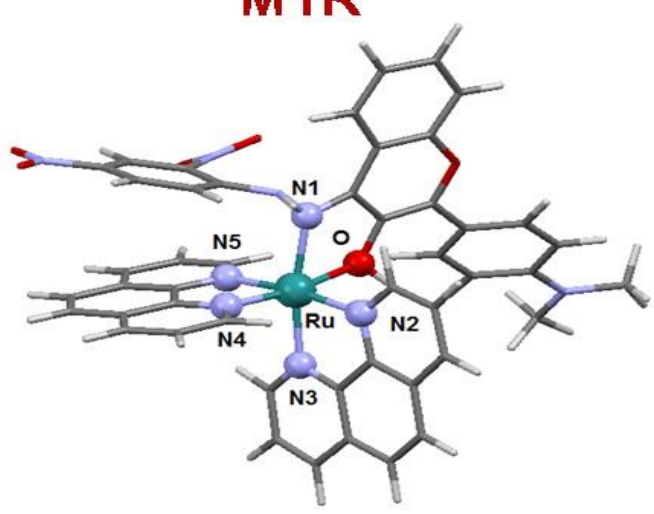

M3R

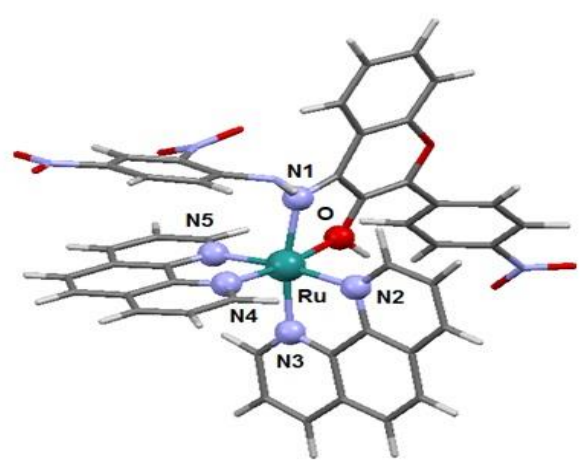

M2R

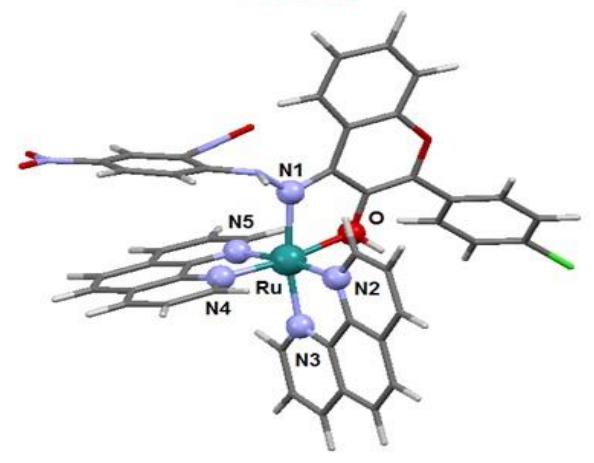

M4R

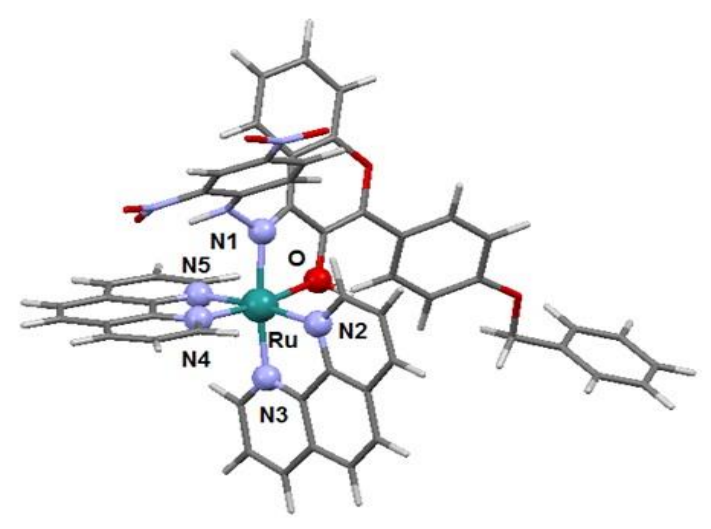

\section{M5R}

Figure 1. Optimized geometry of the complexes. 


\subsection{Biological activities.}

\subsubsection{Antimycobacterial screening.}

The initial antimycobacterial susceptibility testing at $50 \mu \mathrm{m}$ of compounds concentration using Resazurinmicrotiter plate assay resulted in varying growth profile of $M$. smegmatis $\mathrm{mc}^{2}$ (Fig. 2 and 3). The compounds M1R and M4R showed good growth inhibition with no color change from blue to pink. Both M1R and M4R showed good antimycobacterial activity with MIC being $6.25 \mu \mathrm{m}$ in both the cases. The CFU reduction was greater than $99 \%$ at MIC. The drug susceptibility studies (DST) using colorimetric methods are low-cost alternatives to MGIT and BACTEC systems with good correlation[25-27]. The colorimetric indicators such as Alamar blue, MTT, and resazurin have been found to have good specificity, and hence resazurin was used in this study.

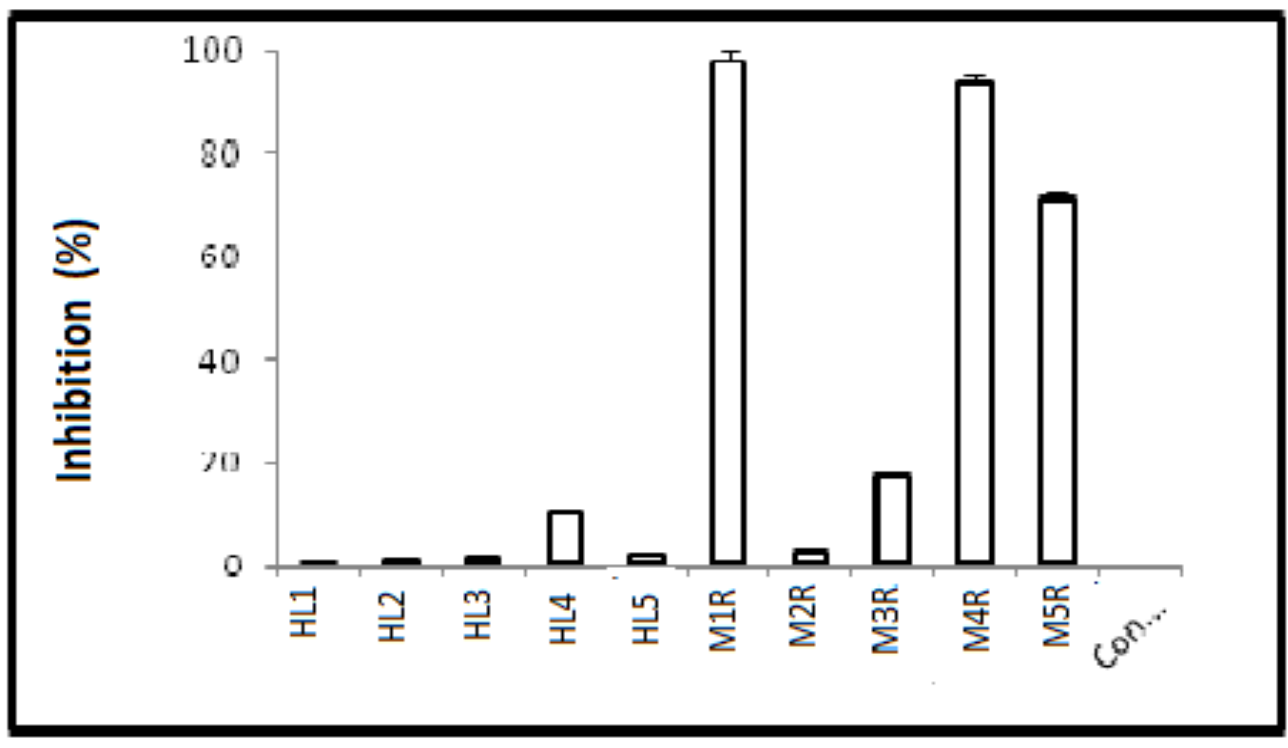

Figure 2. Column plot showing percentage growth inhibition of $M$. smegmatis mc2 at 50 $\mu$ mconcentration.

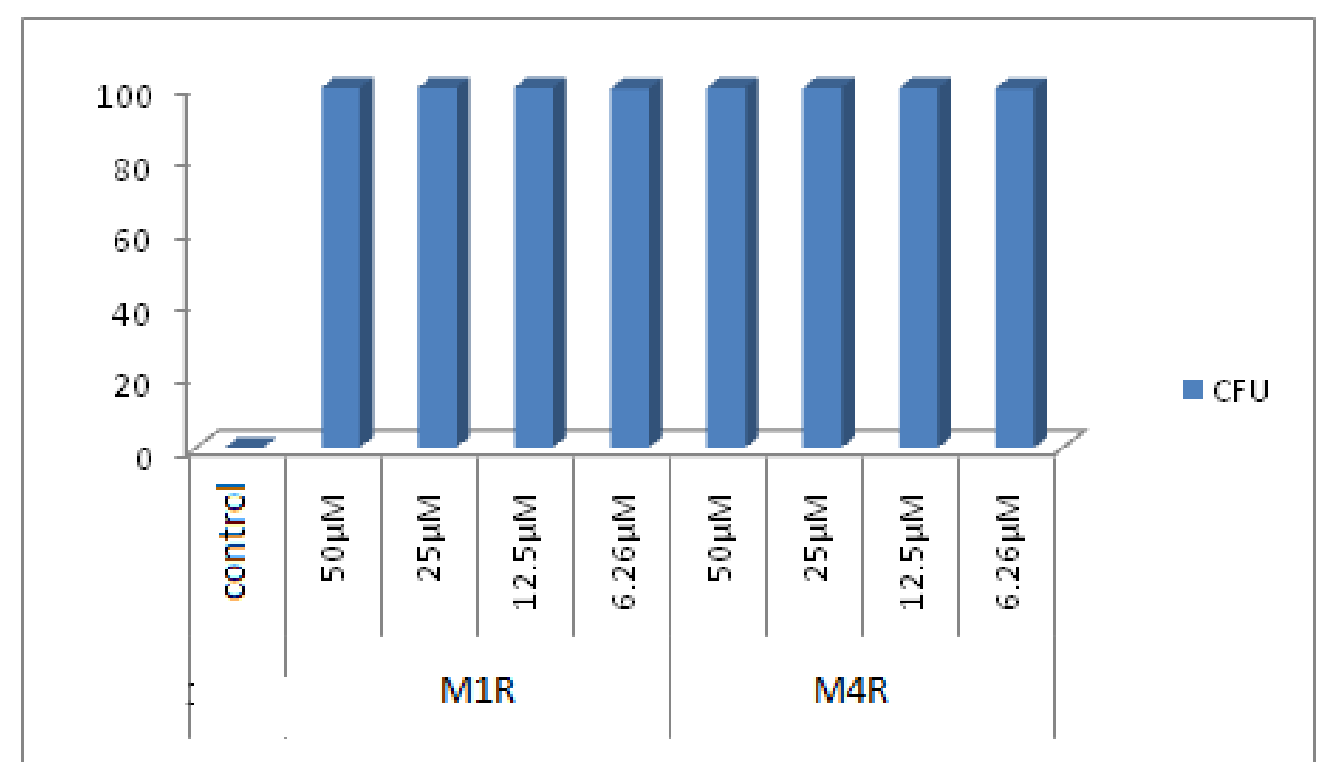

Figure 3. Column plot showing percentage growth inhibition of $M$. smegmatis mc2 in M1R and M4R compound at different concentration $(50 \mu \mathrm{m}, 25 \mu \mathrm{m}, 12.5 \mu \mathrm{m}, 6.25 \mu \mathrm{m})$. 

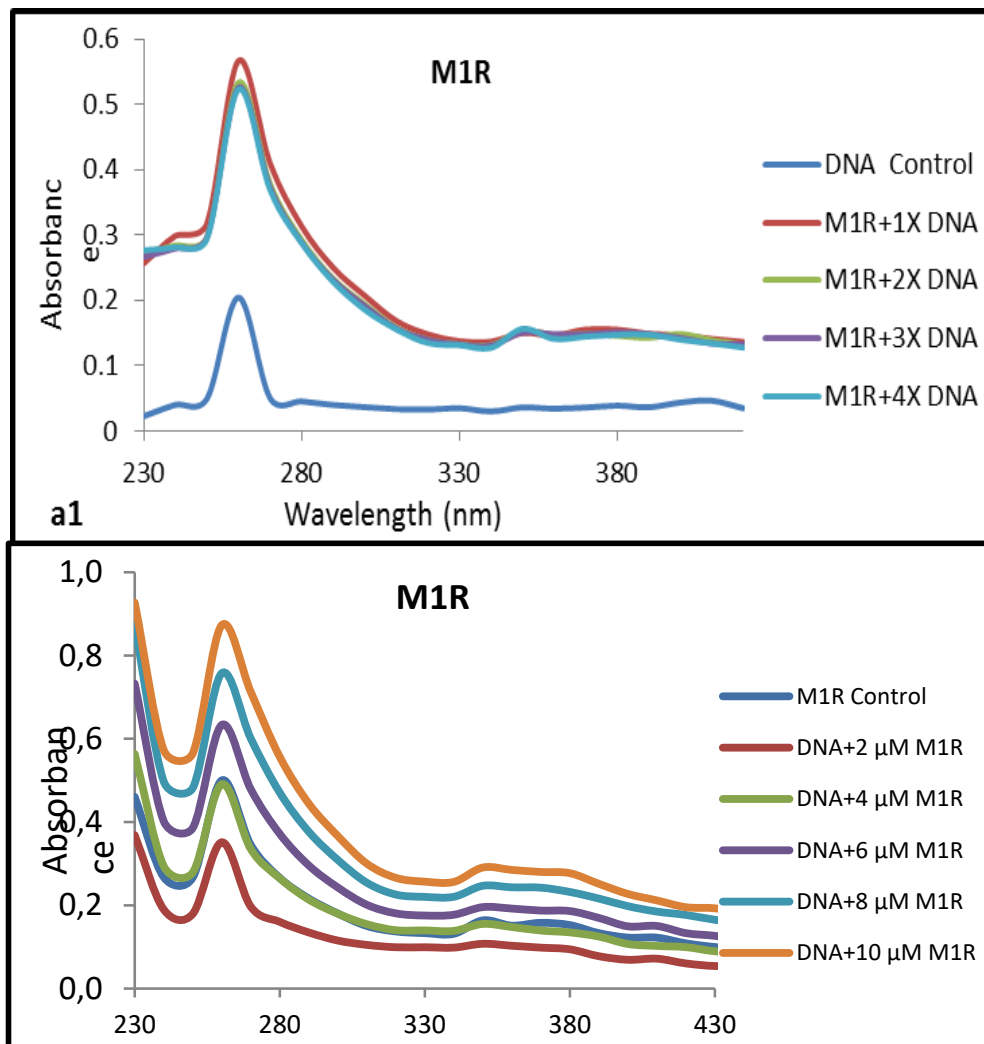

a

Wavelength

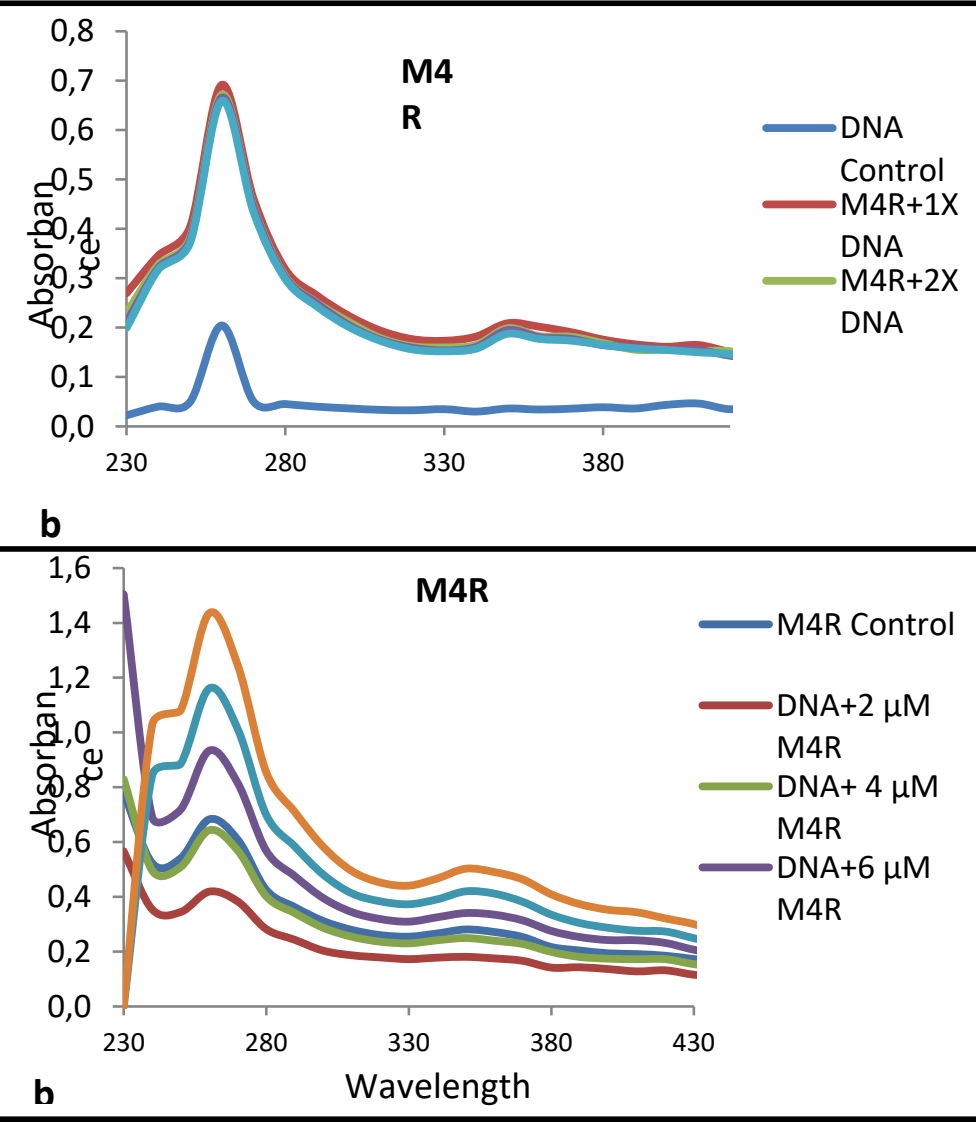

Figure 4. Absorption spectrum of DNA with Ruthenium complexes (a1): Shows the effect of increased DNA concentration on the absorption profile of DNA - Ruthenium complexes (M1R). (a2): Shows the effect of increasing concentrations $(0,2,4,6,8$, and $10 \mu \mathrm{m})$ of Ruthenium complex (M1R) at a fixed concentration of $M$. smegmatis $\mathrm{mc}^{2}$ genomic DNA; (b1): Shows the effect of increasing DNA concentration on the absorption profile of DNA - Ruthenium complex (M4R); (b2): Shows the effect of increasing concentrations (0, 2, 4, 6, 8, and $10 \mu \mathrm{m}$ ) of Ruthenium complex (M4R) at a fixed concentration of $M$. smegmatis $\mathrm{mc}^{2}$ genomic DNA. 
3.6.2. DNA ruthenium complex interaction studies.

The DNA binding studies of M1R and M4R (high percentage of growth inhibition) were performed using $M$. smegmatis $\mathrm{mc}^{2}$ genomic DNA by incubating DNA with different amounts of the metal complex as well as incubating metal complex with different DNA concentrations. The absorbance spectra for M1R suggested that with an increase in DNA concentration, absorbance at $260 \mathrm{~nm}$ decreased slightly (Fig. 4a1). Also, an absorbance spectrum of M1R alone was similar to the spectra of M1R+DNA, and a gradual increase in absorbance was observed with an increase in M1R concentration (Fig.4a2). This lack of increase in absorbance coupled with a small decrease in compound-specific absorbance at 260nm suggested possible masking of absorbance of M1R by DNA. The absorption spectra of DNA at fixed DNA concentration and varied M4R concentrations suggested that the absorbance of the compound was overlapping with absorption by DNA. The absorption spectrum of DNA-M4R was similar to M1R with the absorbance of M4R at 260nm, is almost similar to the absorbance of the compound with DNA. Also, a small decrease in absorbance was observed when DNA concentration was an increase (Fig.4 b1). Similarly, the absorbance of M4R alone was similar to M4R+DNA, and a gradual increase in absorbance was observed with an increase in the concentration of M4R (Fig.4 b2). Hence, to rule out the possible change in absorbing molecules micro-environment and its effect on the absorbance of DNA-compound complex leading to no apparent change in absorbance. An electrophoretic mobility shift assay of DNA and DNA+ compound was performed. In this experiment, the loss of fluorescence of the DNA-ethidium bromide (EtBr) complex was observed with increasing drug concentration (Fig.5 A1, A2, B1, and B2). The DNA-EtBr fluorescence being dependent upon its intercalation with DNA, any change in intercalation leads to loss of fluorescence. This phenomenon was clearly visible through a gradual decrease in fluorescence intensity with no fluorescence being visible at $7.5 \mu \mathrm{M}$ concentration of M1R and M4R. Also, no shearing of DNA was observed upon its interaction with M1R and M4R. This study clearly suggested that both M1R and M4R can modulate the binding of EtBr with DNA leading to loss of fluorescence. The earlier studies exploring the interaction of DNA with reservatrol and genistin observed that both these compounds had de-intercalating properties against EtBr [28]. Similar de-intercalating effects were observed in our study leading to loss of fluorescence of DNAEtBr complex. This also confirms that both M1R and M4R can interact with DNA with possible structural alterations in the DNA double helix.

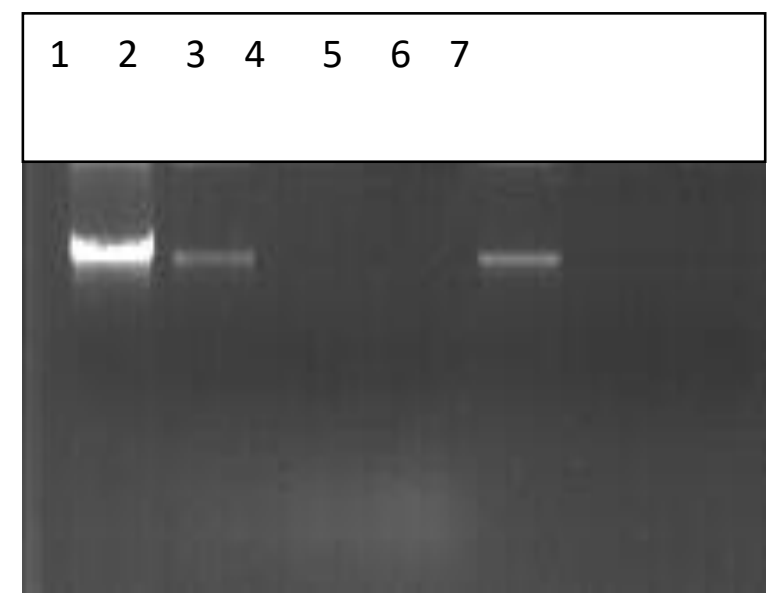

Figure 5. Agarose gel electrophoresis showing a concentration-dependent effect on DNA+EtBr fluorescence. Lane 1 is Lane 1- M. smegmatis mc2 genomic DNA, Lane 2, 3, and 4 are DNA with 2.5, 5, and 7.5 $\mu \mathrm{m}$ concentrations of M1R. Lane 5, 6, and 7 are DNA with $2.5 \mu \mathrm{m}, 5 \mu \mathrm{m}$, and $7.5 \mu \mathrm{m}$ concentration of M4R. 


\section{Conclusions}

The results from present studies are promising as they suggest the possibility of coordination complexes as a new source of metal-based antimycobacterial drugs. The $\mathrm{Ru}$ (II) complexes with electron donation and withdrawing group in the ligands also show strong DNA binding ability and show very promising activity against $M$. smegmatis $\mathrm{mc}^{2}$. This study also suggests that binding of both M1R and M4R with DNA affects the EtBr interaction with DNA, and possible structural alterations in DNA double helix may be one of the reasons for it. This could be a new class of molecules with potential antimycobacterial properties and needs to be explored further as a class of molecules. The resazurin based microtiter plate assay offers a cost-effective assay for rapid screening of antimycobacterial compounds using M.smegmatis $\mathrm{mc}^{2}$ as a test organism. The $M$. smegmatis $\mathrm{mc}^{2}$ based assays are fast and convenient to perform in a BSL-2 laboratory set-up, thus greatly simplifying the initial screening efforts for the rapid and safe screening of antimycobacterial compounds.

\section{Funding}

This research received no external funding.

\section{Acknowledgments}

Author Ashok K. Singh would like to thank DST -PURSE for the instrumentation Facility. The authors are also grateful to the department of chemistry, Lucknow University, Lucknow and Director, CSIR-CDRI, Lucknow, India, for support to carry out the Biological studies.

\section{Conflicts of Interest}

The authors declare no conflict of interest.

\section{References}

1. Montelongo-Peralta, L. Z.; León-Buitimea, A.; Palma-Nicolás, J.P.; Gonzalez- Chrislen, J.; MoronesRamirez, J. R.; Antibacterial Activity of combinatorial treatments composed of transition-metal/antibiotics against Mycobacterium. tuberculosis. Sci. Rep 9, 2019, 5471, https://doi.org/10.1038/s41598-019-420495 .

2. Aly, S.A.; Fathalla, S.K. Preparation, characterization of some transition metal complexes of hydrazone derivatives and their antibacterial and antioxidant activities. Arabian Journal of Chemistry 2020, 13, 37353750,https://doi.org/10.1016/j.arabjc.2019.12.003.

3. Singh, A.K.; Saxena, G.; Singh, R.K.; Kumari, L.; Sharma, R.; Singh, S.K.; Arshad, M. Design, Synthesis, Characterization and Biological Evaluation of Ruthenium Complexes of Flavonethiosemicarbazones as Antiproliferative and Mycobacterial Activities. Chemistry Select 2018, 3, 1268212689, https://doi.org/10.1002/slct.201802929.

4. Robert, B. P.; Elmes, G.J. R.; Maria, L. E.; Daniel, O. F.; Jonathan, A. K.; Mark L, Williams, D. C.; Quinn, S. J.; Gunnlaugsson T.; Synthesis, Characterization, and Biological Profiling of Ruthenium(II)-Based 4Nitro- and 4-Amino-1, 8-naphthalimide Conjugates. Inorganic Chemistry 2020, 59, 10874-10893, https://doi.org/10.1021/acs.inorgchem.0c01395.

5. Zhou, Y.; Xu, Y,; Lu, L.; Ni, J.; Nie, i.; Cao, J.; Qi Zhang Y. J.; Luminescent ruthenium(II) polypyridyl complexes acted as radiosensitizer for pancreatic cancer by enhancing radiation-induced DNA damage.Theranostic, 2019, 9, 6665-6675, https://doi.org/10.7150/thno.34015.

6. Guan, S.; Pan, T.; Zhang, Y.; Zeng, Z.; Mu, L.; Duo Zhu, Chang. B.; Zheng, K.; Qian, J.; Xie, Q.; Mei, W.; Tang, W.; Bai ,M. Synthesis, DNA-binding, and antitumor activity of polypyridyl-ruthenium(II) complexes $\left[\mathrm{Ru}(\mathrm{L})_{2}(\mathrm{DClPIP})\right] \quad(\mathrm{L}=$ bpy, phen; $\quad$ DClPIP $=2$-(2,4-dichlorophenyl)-1H-imidazo[4,5- $f] \quad[1,10]$ phenanthroline). J.Coord. Chem. 2019, 72, 2050-2064, https://doi.org/10.1080/00958972.2019.1630614. 
7. Hickson, J. R.;Samuel, J. H.; Bamforth C.; McGuire, J.; Wilson, C., Farnaby, S. S.; Joy, H. The modular synthesis of rare earth-transition metal heterobimetallic complexes utilizing a redox-active ligand, Dalton Trans., 2018, 47, 10692-1070, https://doi.org/10.1039/c8dt01262h.

8. Lim, H.; Heo, M.Y.; Kim, H.P. Flavonoids: broad spectrum agents on chronic inflammation. Biomol. Ther. (Seoul) 2019, 27, 241, https://doi.org/10.4062/biomolther.2019.034.

9. Tölle, J.; Böckers, M.; Neugebauer, J. Exact subsystem time-dependent density-functional theory. The Journal of chemical physics 2019, 150, 181101; https://doi.org/10.1063/1.5097124.

10. Muthumari, S.; Ramesh, R.; Synthesis and Structure of Ru(II) Complexes of Thiosemicarbazone: Highly Selective Catalysts for Oxidative Scission of Olefins to Aldehydes. Chem. Selec. 2018, 3, 3036-3041, https://doi.org/10.1002/slct.201800163.

11. Farhadi F.; Khameneh, B.; Iranshahi, M.; Iranshahy, M.; Antibacterial activity of flavonoids and their structure-activity relationship: An update review. Phytoth. Res. 2019, 1-29, https://doi.org/10.1002/ptr.6208.

12. Abu-Melha, S. Design, Synthesis and DFT/DNP Modeling Study of New 2-Amino-5-arylazothiazole Derivatives as Potential Antibacterial Agents. Molecules 2018, 23, 434, https://doi.org/10.3390/molecules23020434.

13. Singh, A.; Singh, R.; Arshad, M.; Siddiqui, S.; Singh, S.; Sinha, R. Synthesis, characterization, cytotoxicity and antimycobacterial screening of Some p-substituted benzyl thiosemicarbazones. Indian Journal of Chemistry - Section B Organic and Medicinal Chemistry 2014, 53, 769-774.

14. Akatsuka, K.; Abe, R.; Takase T.; Oyama D.; Coordination Chemistry of Ru(II) Complexes of an Asymmetric Bipyridine Analogue: Synergistic Effects of Supporting Ligand and Coordination Geometry on Reactivities, Molecules., 2020, 25, 27, https://doi.org/10.3390/molecules25010027.

15. Tan, S. S.; Yanagiasawa, S.; Inagaki, K.; Kassim, M.B.; Experimental and computational studies on ruthenium(ii) bis-diimine complexes of $N, N^{\prime}$-chelate ligands: the origin of changes in absorption spectra upon oxidation and reduction. Phys. Chem. Chem. Phys., 2019, 21, 7973-7988, https://doi.org/10.1039/C8CP05016C.

16. Schoutrop, E. L. M.; Brouwer, M. A. E.; Jenniskens, J. C. A.; , Ferro B. E.; Mouton J. W.; Aarnoutse, R. E, Ingen, J. V. The stability of antimycobacterial drugs in media used for drug susceptibility testing. Diagn Microbiol Infect Dis. 2018, 92, 305-308, https://doi.org/10.1016/j.diagmicrobio.2018.06.015.

17. Prajapati, N. P.; Patel, H. D.Novel thiosemicarbazone derivatives and their metal complexes: Recent development Synth. Commun. 2019, 21, 2767-2804, https://doi.org/10.1080/00397911.2019.1649432.

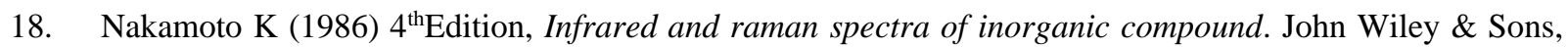
1986; pp 225-226, https://doi.org/10.1002/9780470405840.

19. Kumar I. V.; Nath G. R.; Synthesis, characterization and biological studies of cobalt(II), nickel(II), copper(II) and zinc(II) complexes of vanillin-4-methyl-4- phenyl-3-thiosemicarbazone. 2019, 131, https://doi.org/10.1007/s12039-019-1658-x.

20. He, C.; Yu, S.; Ma, S.; Cheng, F. Synthesis, characterization, photophysical, and redox properties of three trinuclear $\mathrm{Ru}(\mathrm{II})$ polypyridyl complexes possessing 5-amino-1,10-phenanthroline ligands. Transit.Met.Chem. 2019, 44, 515-524, https://doi.org/10.1007/s11243-019-00309-3

21. Viala, C.; Coudret, C. An expeditious route to cis-Ru(bpy) $2 \mathrm{C} 12$ (bpy=2,2'-bipyridine) using carbohydrates as reducers. Inorg. Chim. Acta 2006, 359, 984-989, https://doi.org/10.1016/j.ica.2005.07.019.

22. Xu, S.; Smith, J.E.T.; Weber, J.M. The electronic spectrum of cryogenic ruthenium-tris-bipyridine dications in vacuo. The Journal of chemical physics 2016, 145, 024304, https://doi.org/10.1063/1.4955262.

23. Singh, A.K.; Saxena, G.; Sahabjada; Arshad, M. Synthesis, characterization and biological evaluation of ruthenium flavanol complexes against breast cancer. Spectrochimica Acta Part A: Molecular and Biomolecular Spectroscopy 2017, 180, 97-104, https://doi.org/10.1016/j.saa.2017.02.056.

24. Idemudia, O.G.; Hosten, E.C. Spectroscopy, crystal and molecular structures of new 4-acylpyrazolone dinitrophenylhydrazones. Crystals 2016, 6, 127, https://doi.org/10.3390/cryst6100127.

25. Miotto, P.; Zhang, Y.; Maria Cirillo D.; Yam, Wing. C.; Drug resistance mechanisms and drug susceptibility testing for tuberculosis. Respirology, 2018, 23, 1098-1113, https://doi.org/10.1111/resp.13393.

26. Bisceglie F.; Orsoni N.; Pioli, M.; Bonati, P.; Rivetti C.; Amidani, Davide.; Montalbano, S.; Annamaria B.; Pelosi, G. Cytotoxic activity of copper(ii), nickel(ii) and platinum(ii) thiosemicarbazone derivatives: interaction with DNA and the H2A histone peptide. Metallomics, 2019, 11, 1729-1742, https://doi.org/10.1039/C9MT00166B. 
27. Usha, S.; Johnson, I.M.; Malathi, R. Modulation of DNA intercalation by resveratrol and genistein. Mol. Cell. Biochem. 2006, 284, 57-64, https://doi.org/10.1007/s11010-005-9013-6.

28. Salehi, B.; Mishra, A. P.; Nigam, M., Sener, B.; Kilic, M.; Sharifi-Rad, M.; Tsouh Fokou, P. V.; Martins. N.; Sharifi-Rad, J.Resveratrol: A Double-Edged Sword in Health Benefits. Biomedicines. 2018, 6, 91, https://doi.org/10.3390/biomedicines6030091. 


\section{Supplementary files}

Figure S1. IR Spectra of compounds.

a. HL1

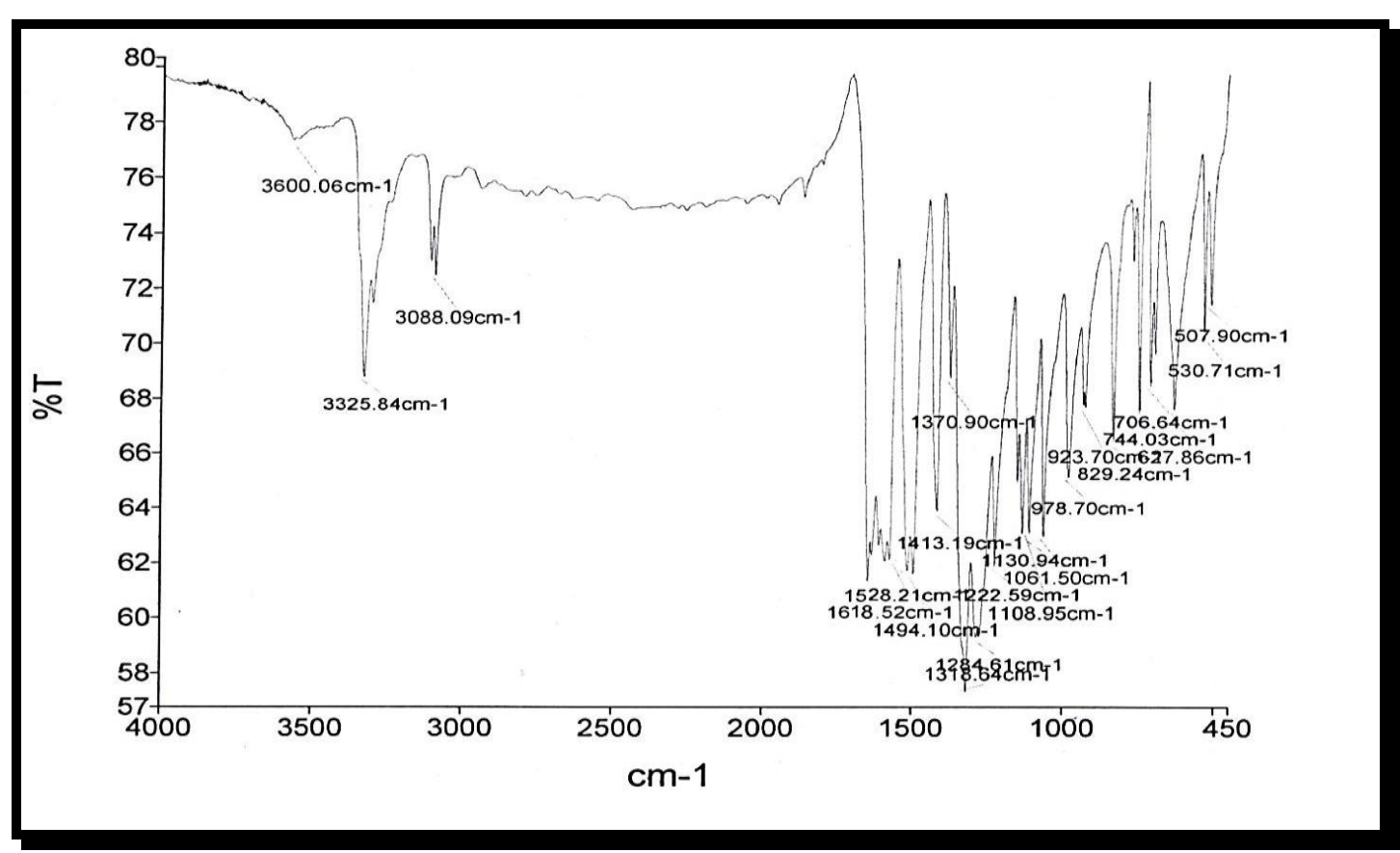

b. M1R

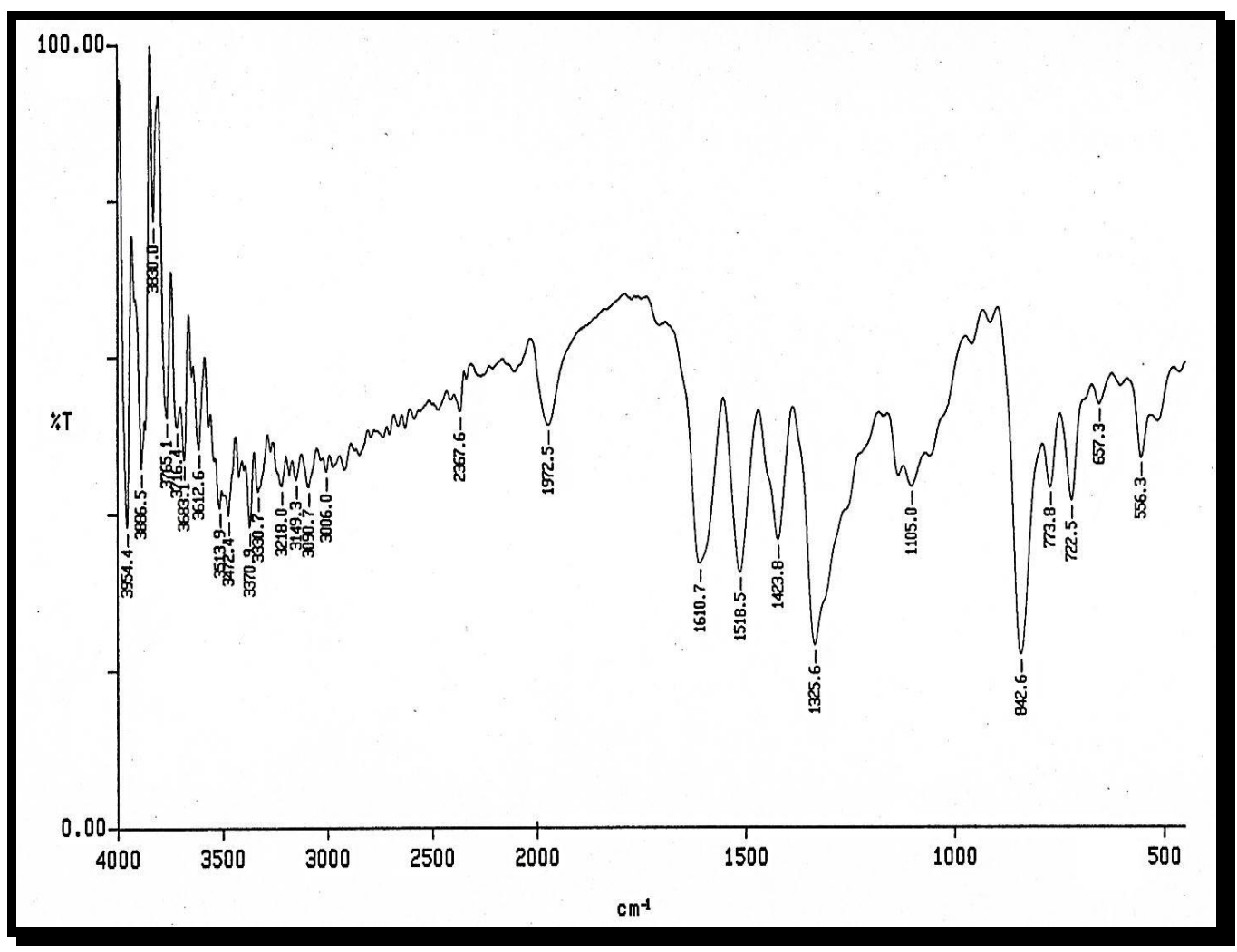


c. HL2

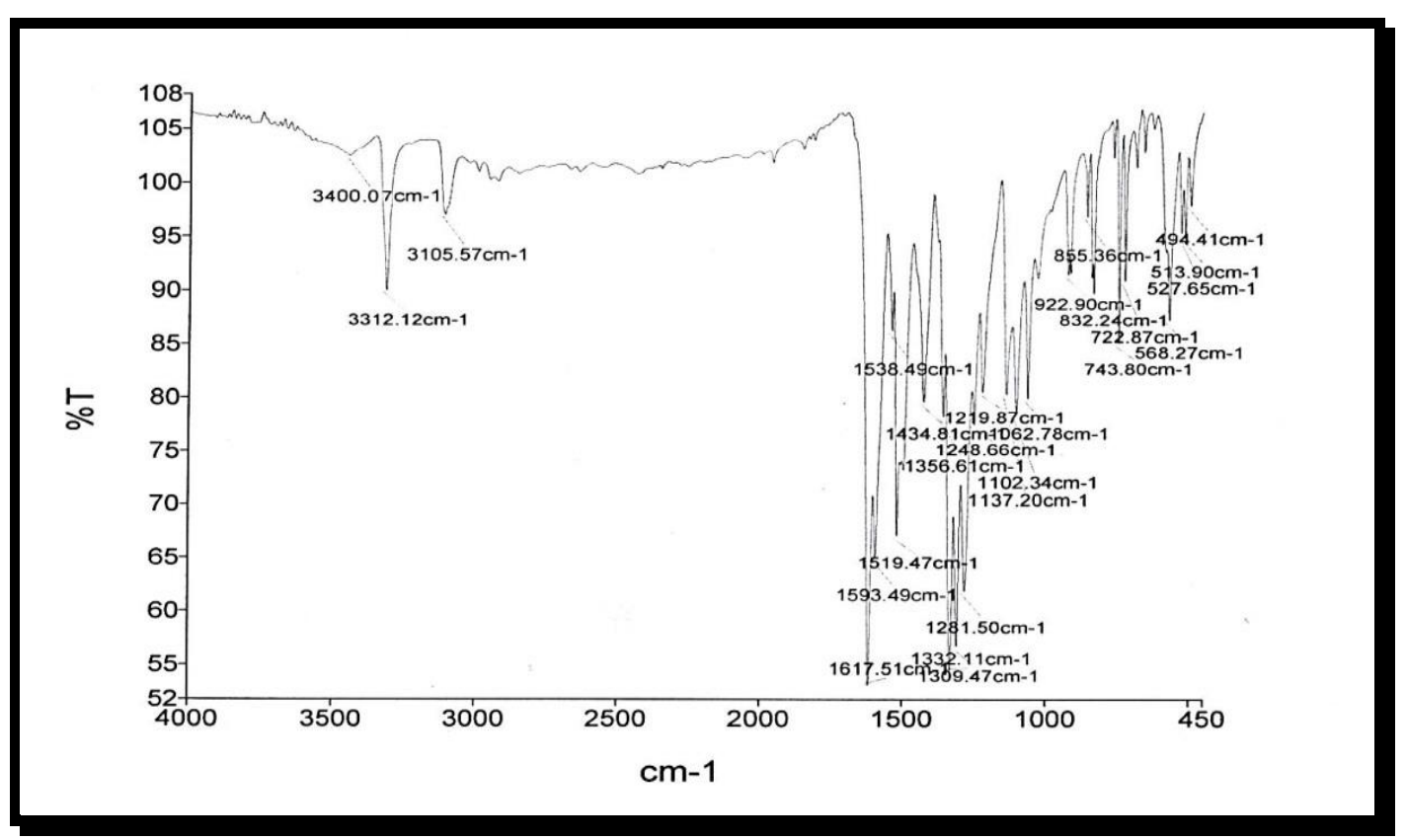

d. $\mathrm{M} 2 \mathrm{R}$

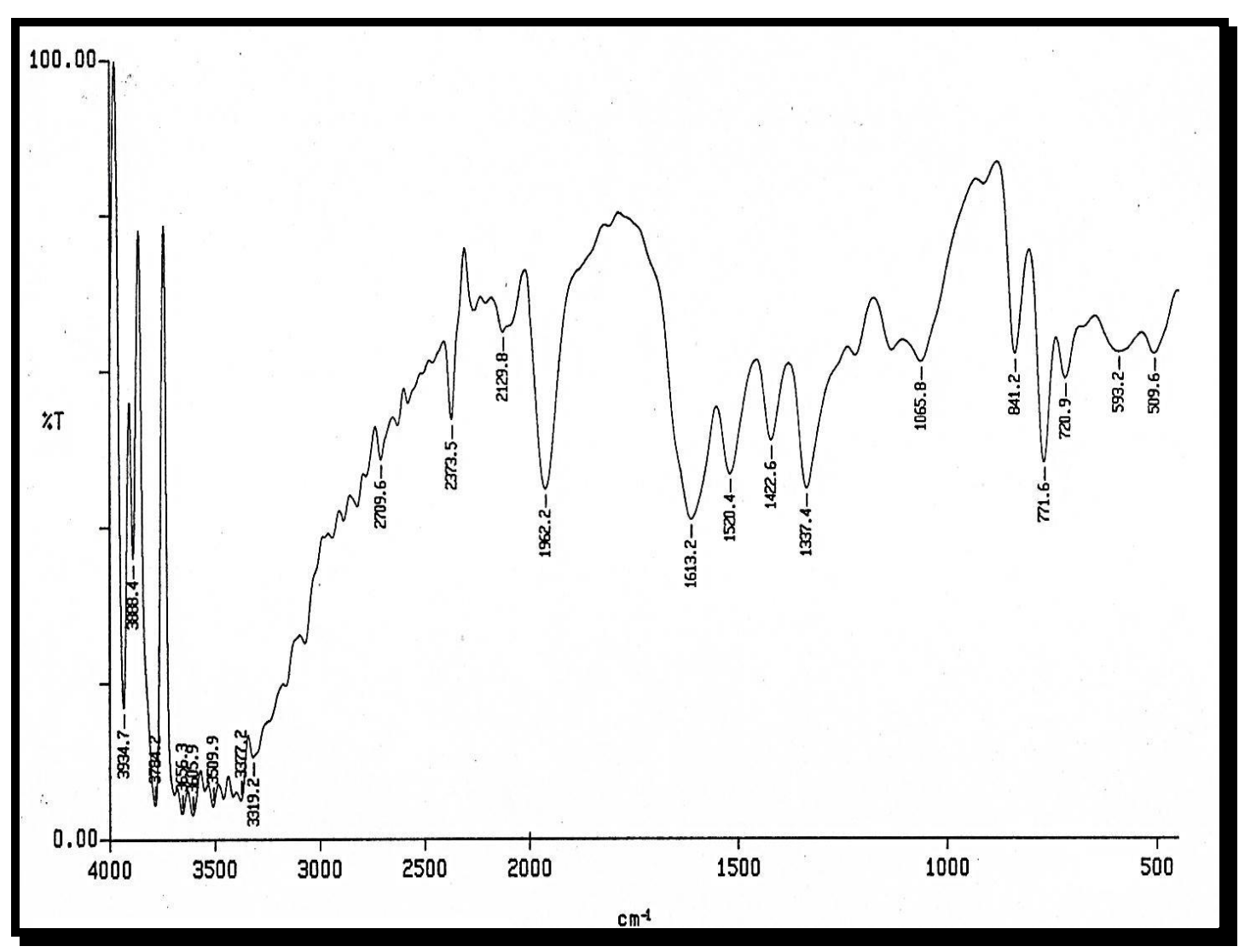


e. HL3

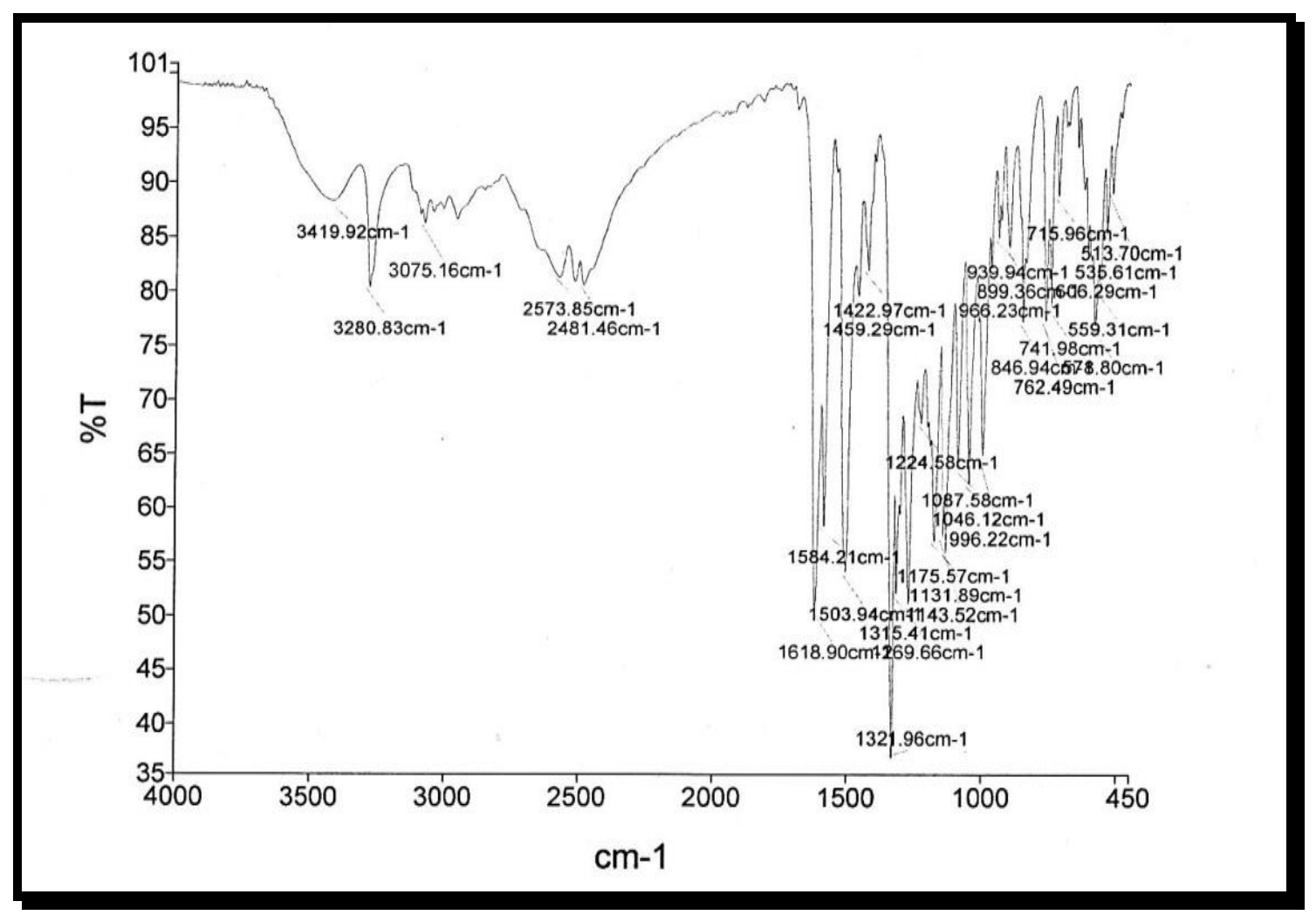

f. M3R

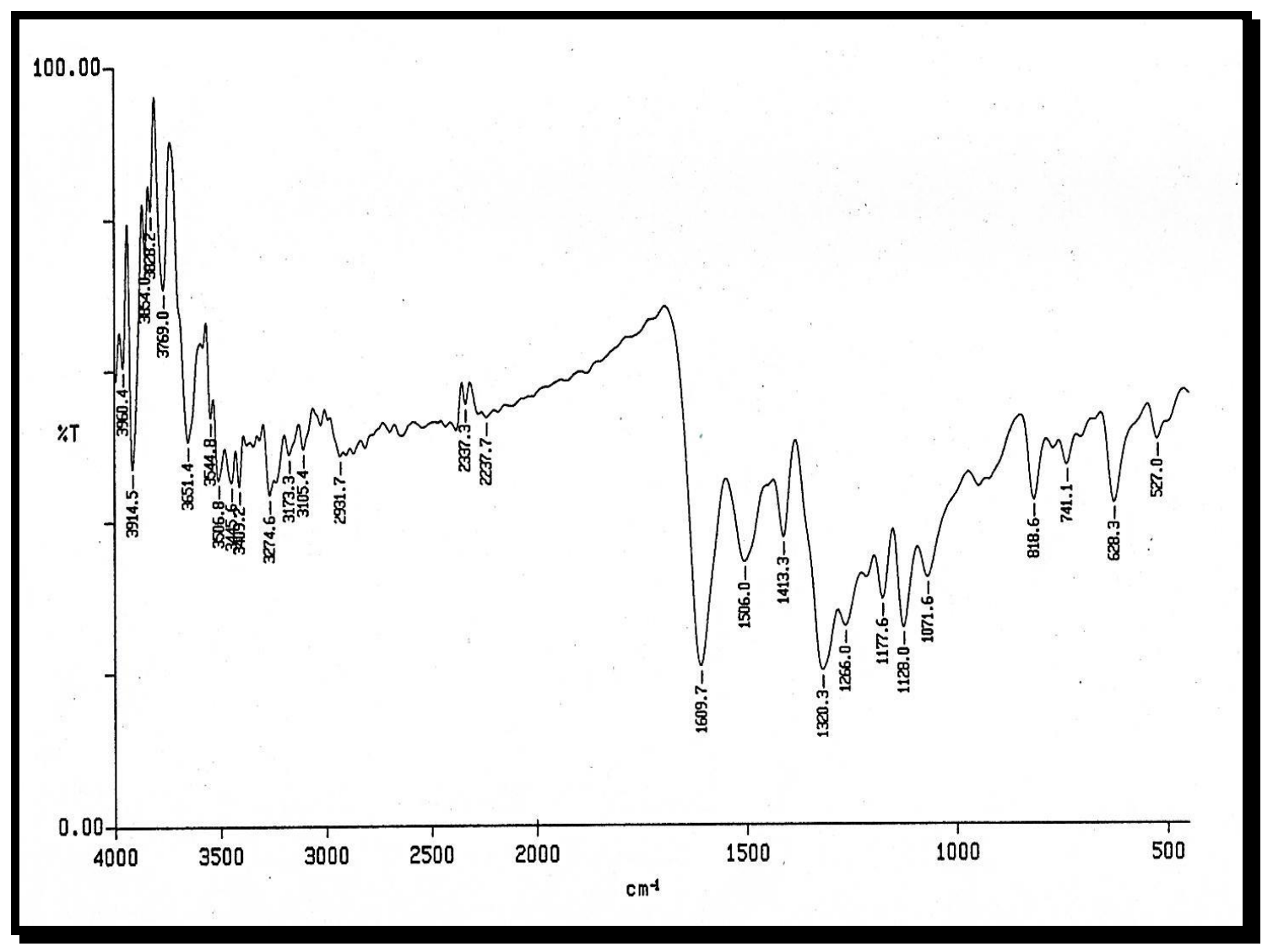




\section{g. HL4}

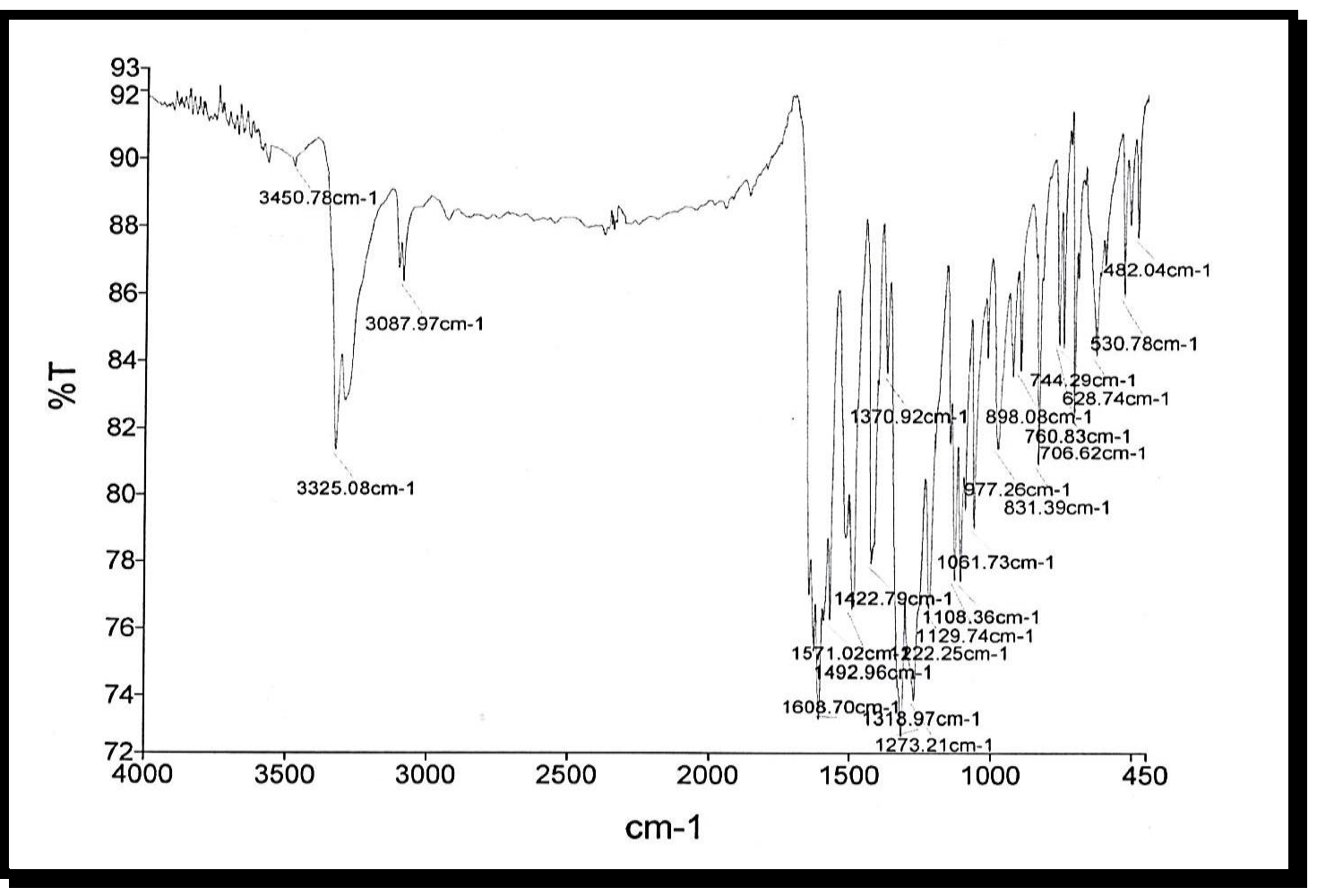

h. M4R

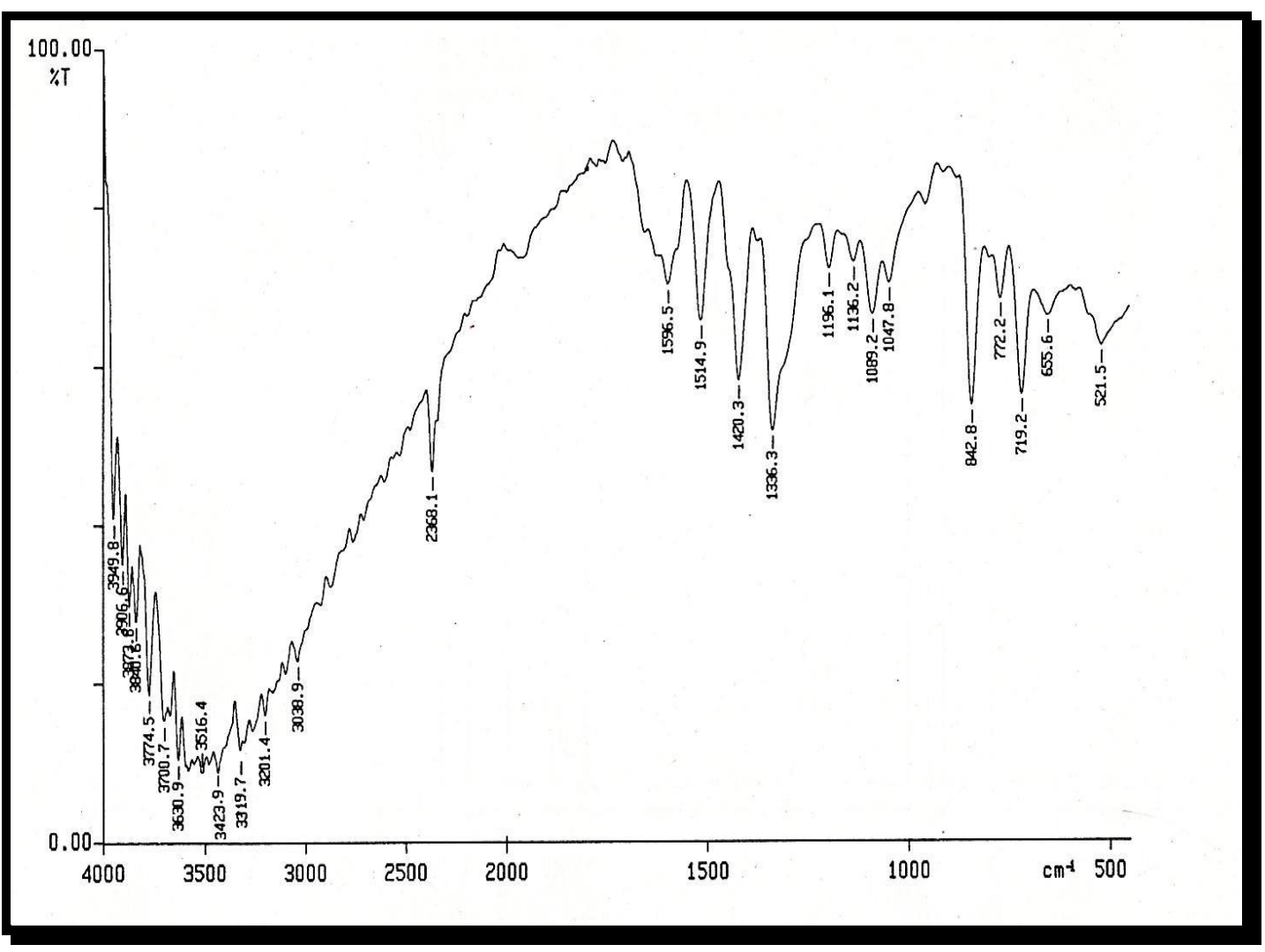




\section{i. HL5}

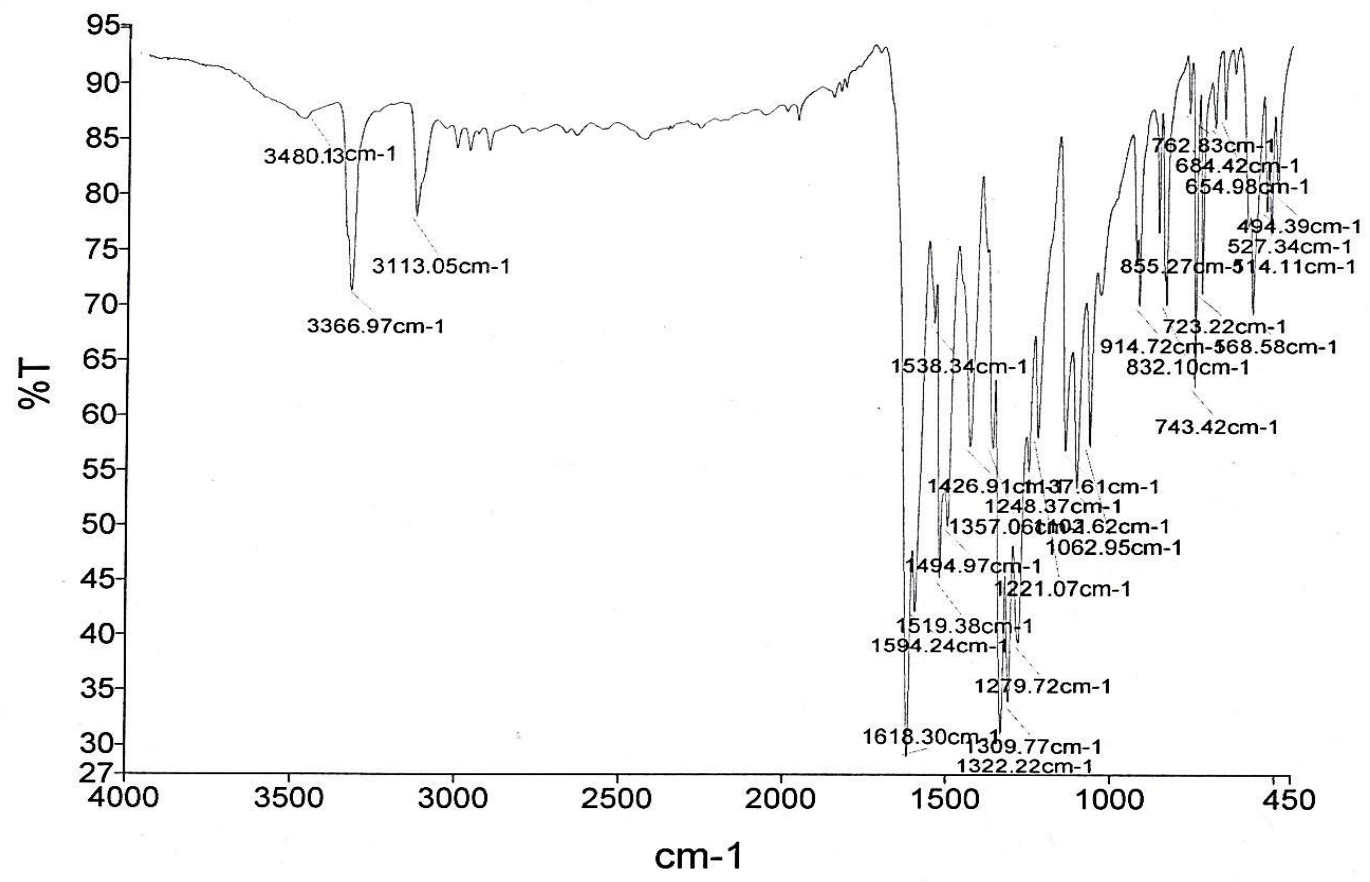

j. M5R

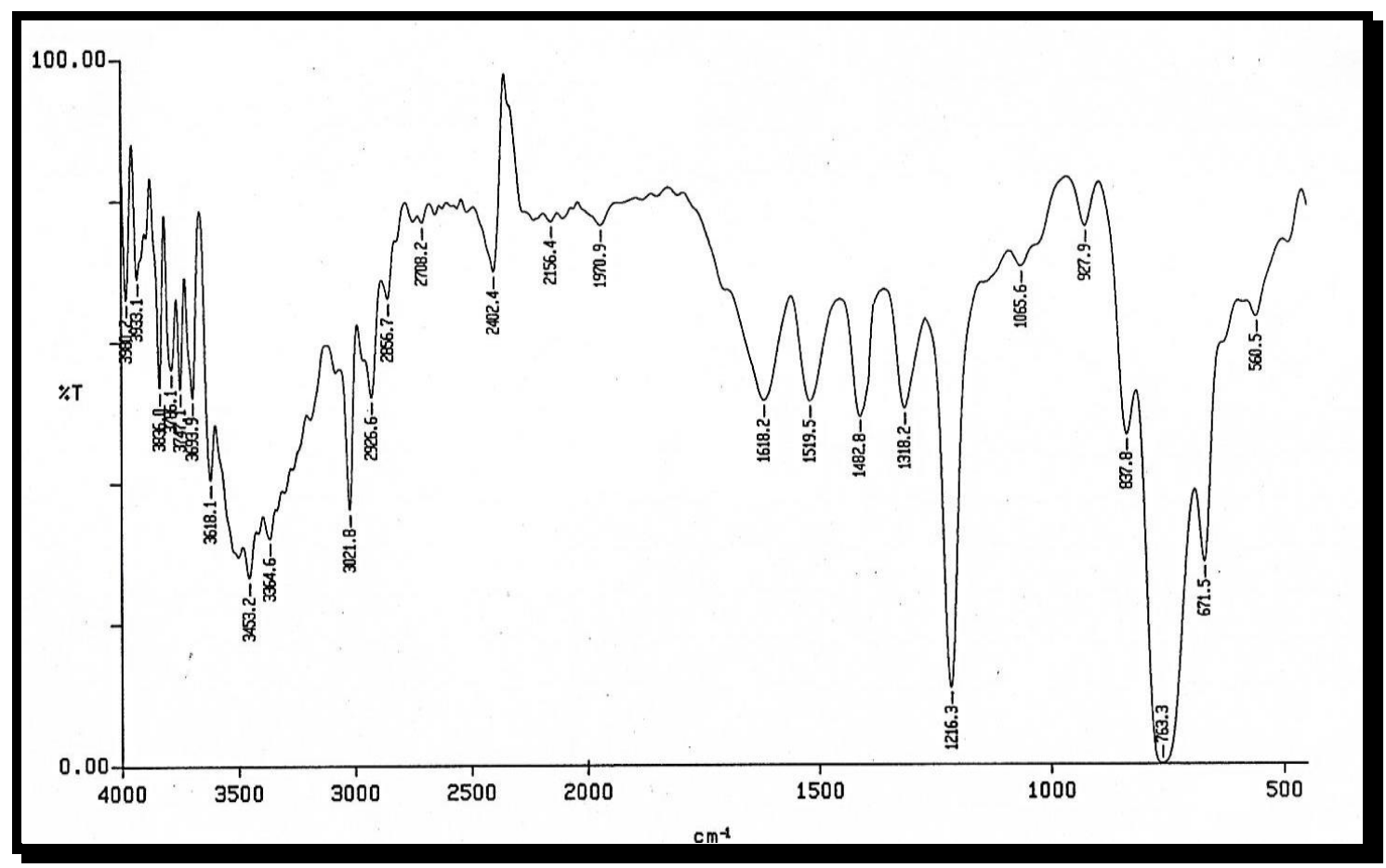


Figure S2. ${ }^{1}$ H NMR of compounds.

a. HL1

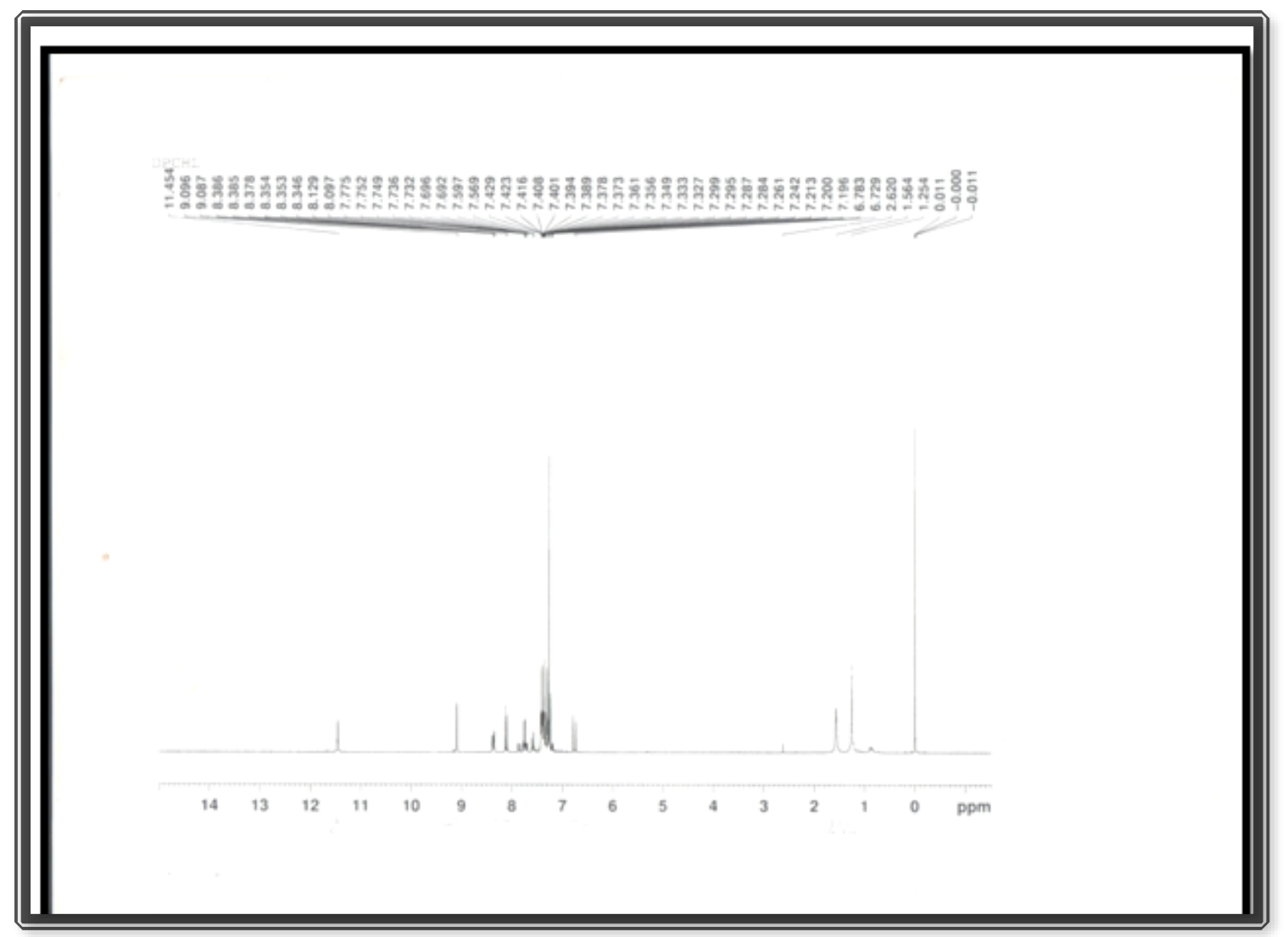

b. HL2

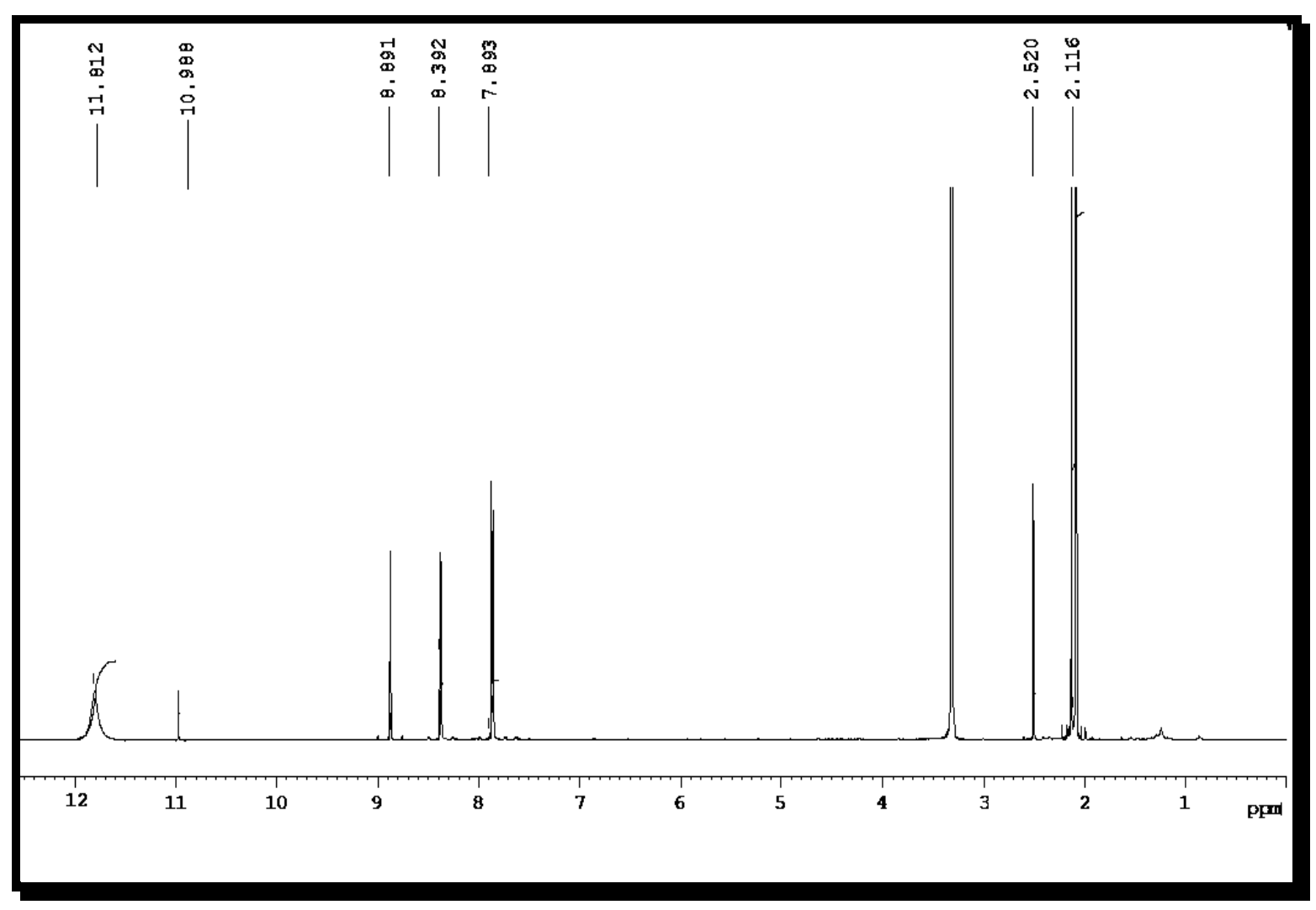


c. HL3

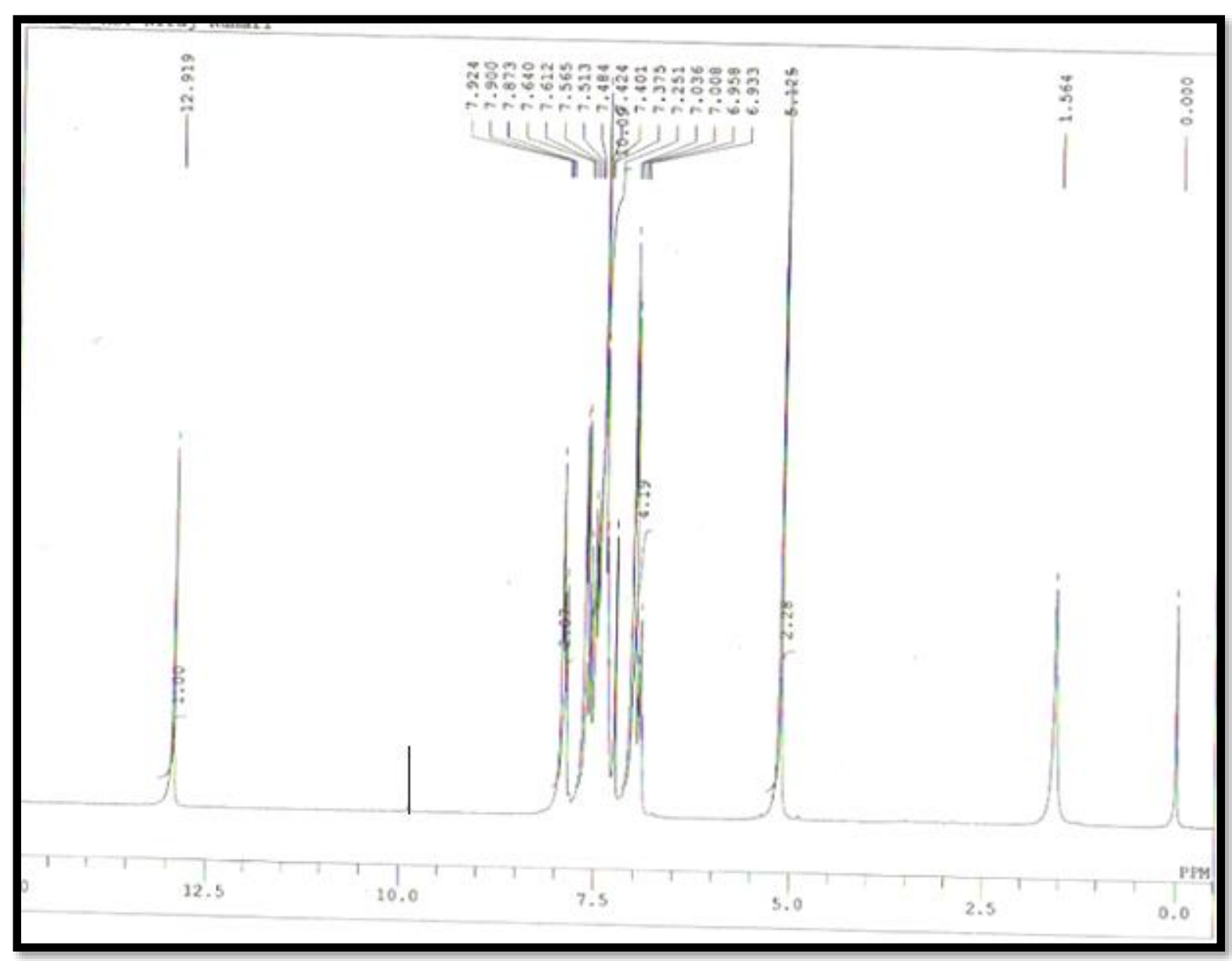

d. HL4

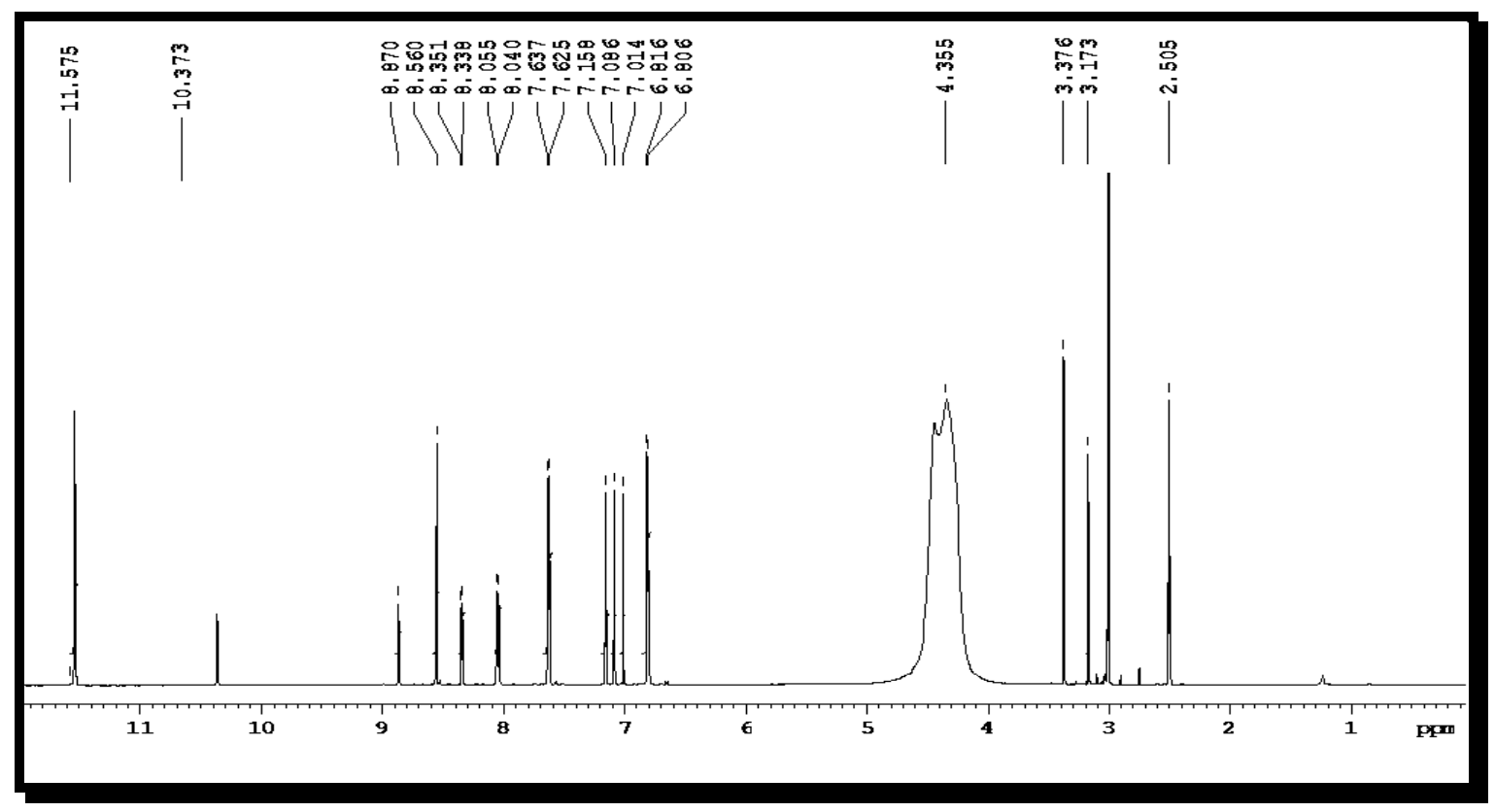




\section{e. HL5}

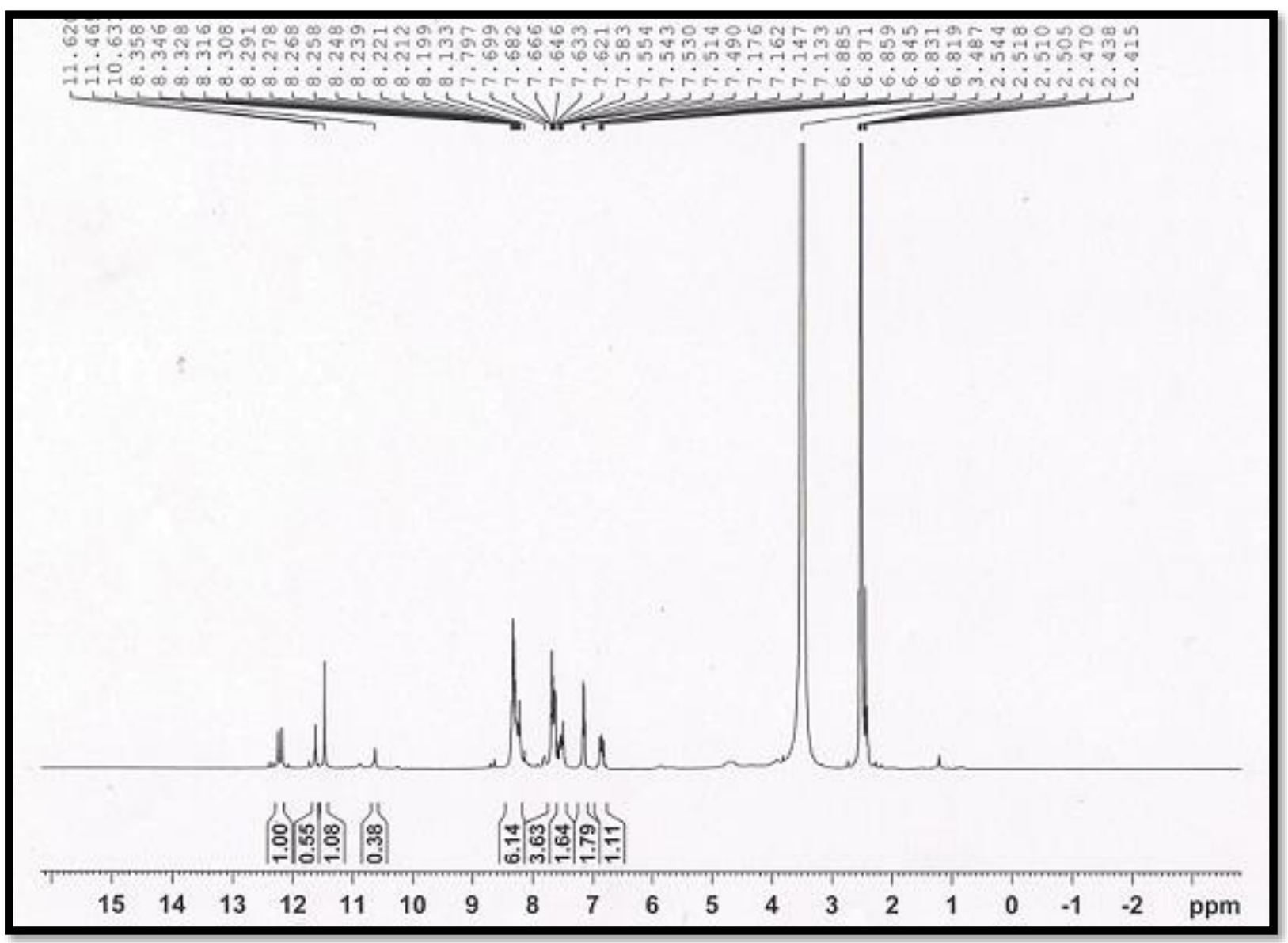

f. M1R

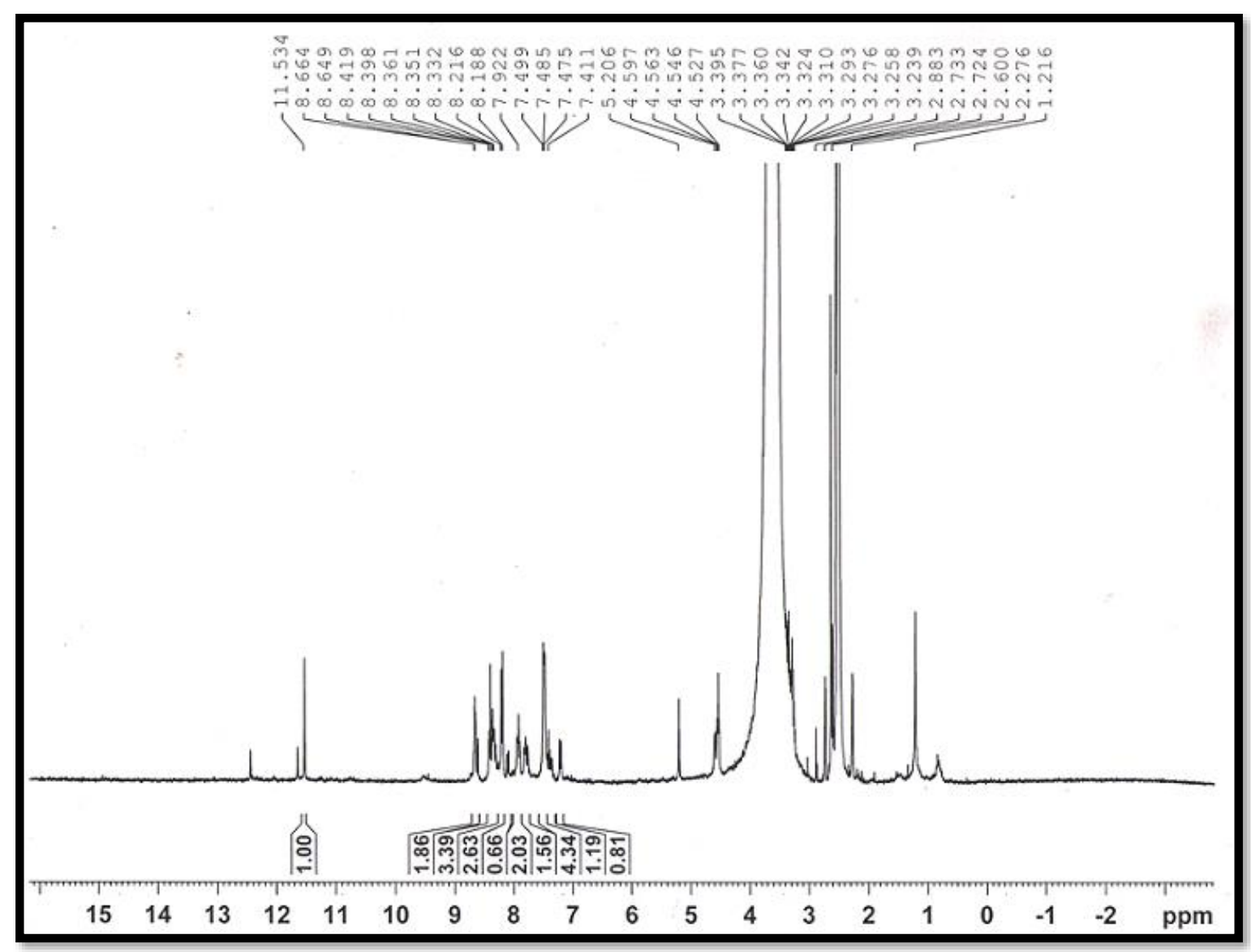




\section{g. $\mathrm{M} 2 \mathrm{R}$}

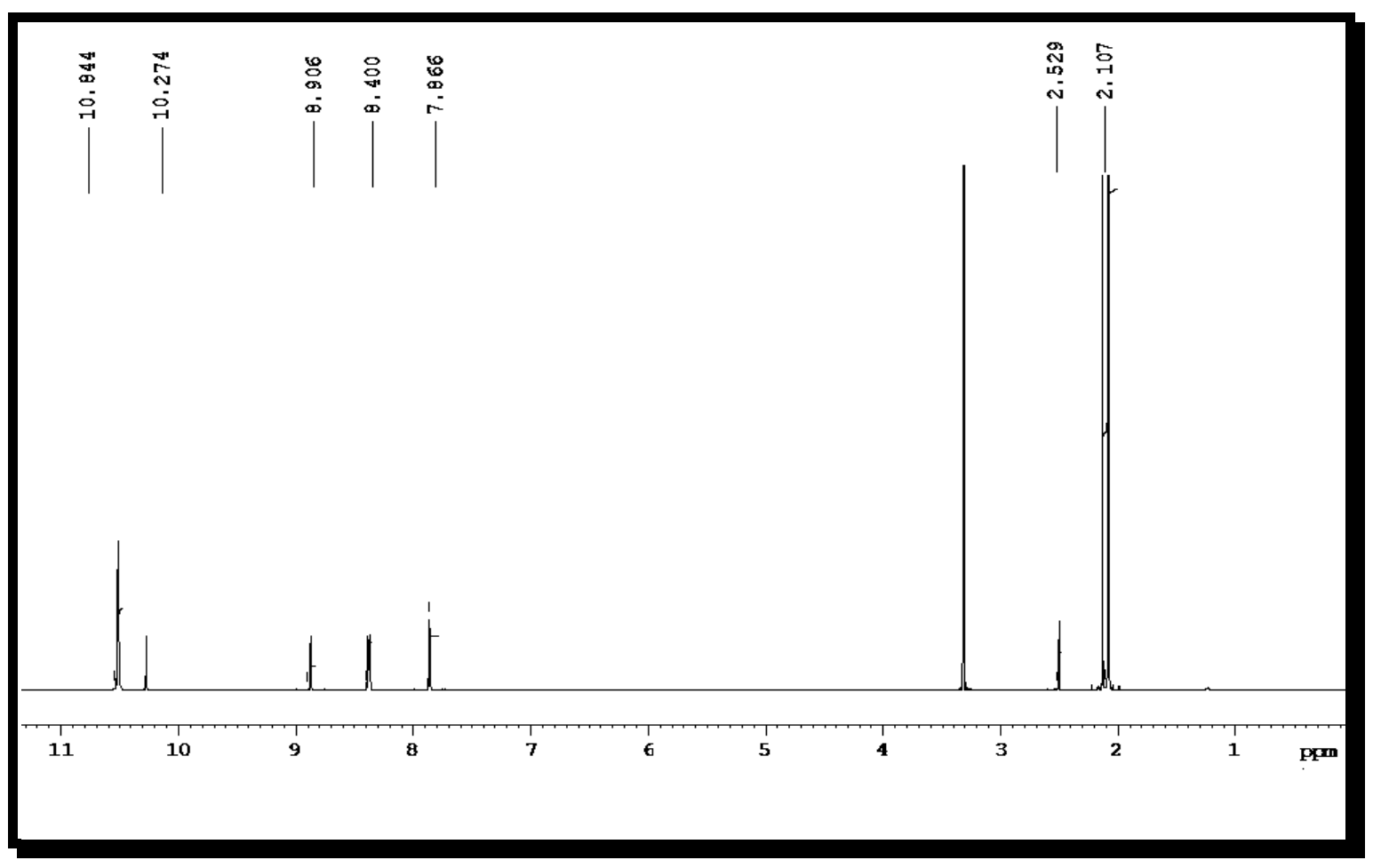

h. M3R

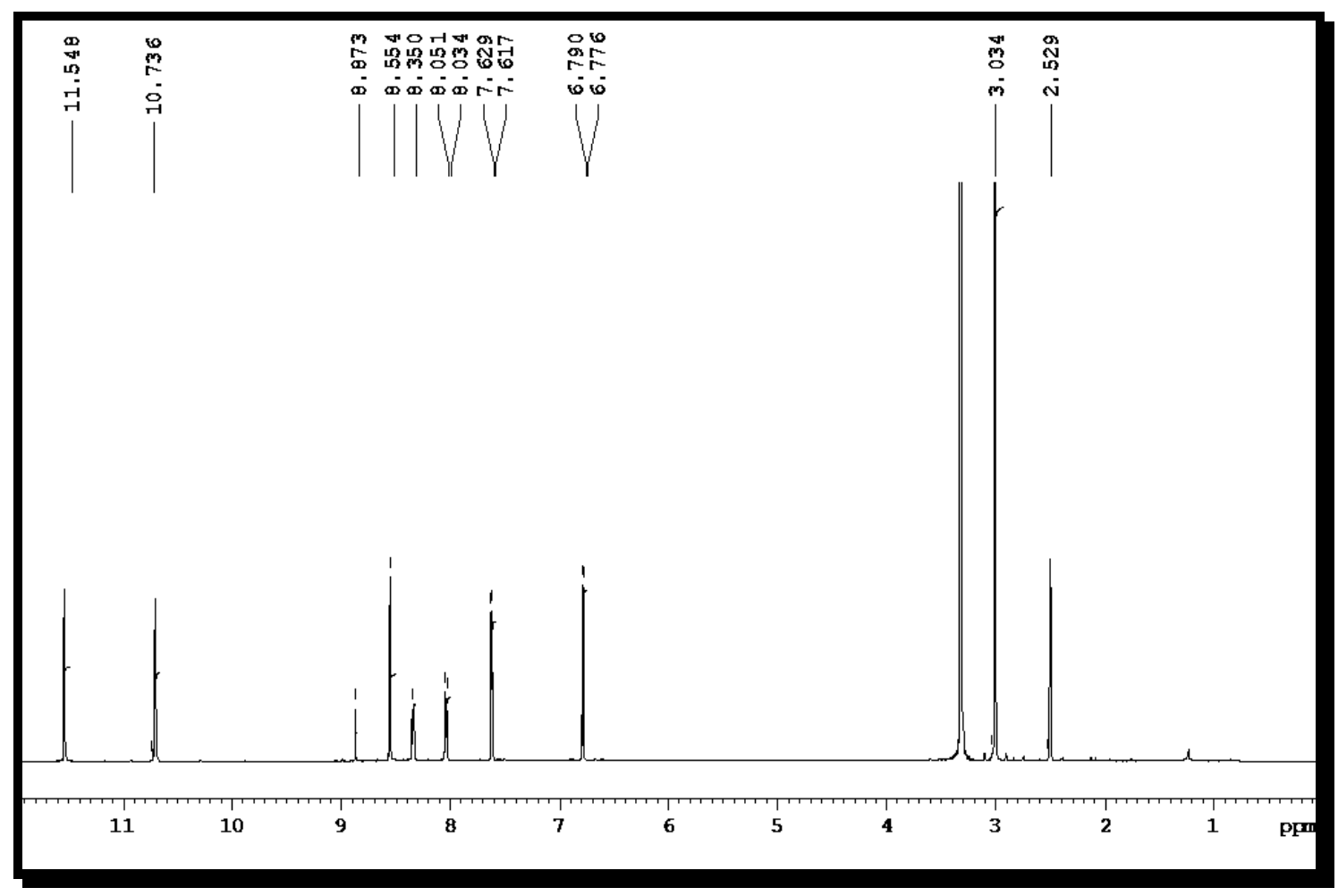




\section{i. $\mathrm{M} 4 \mathrm{R}$}

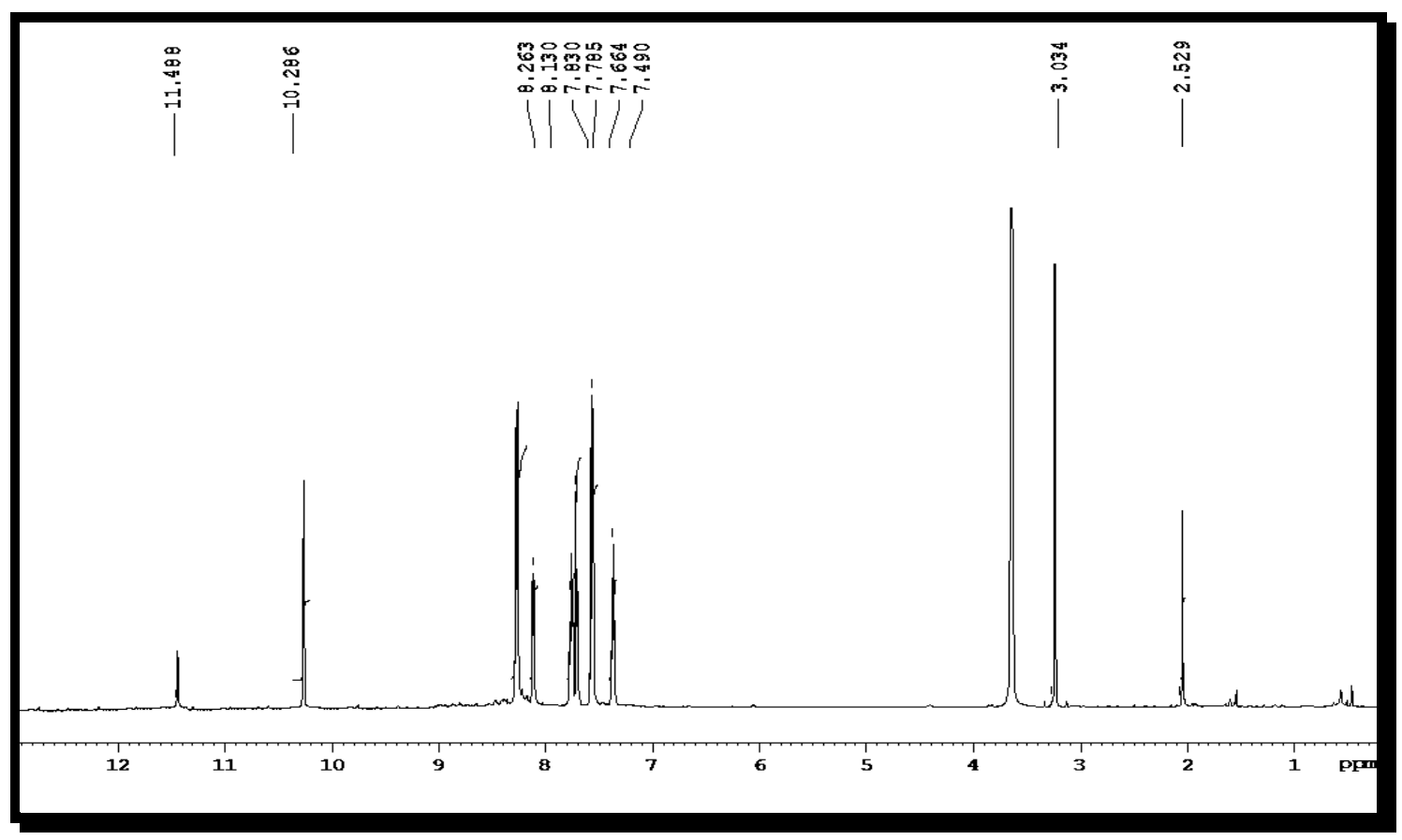

j. M5R

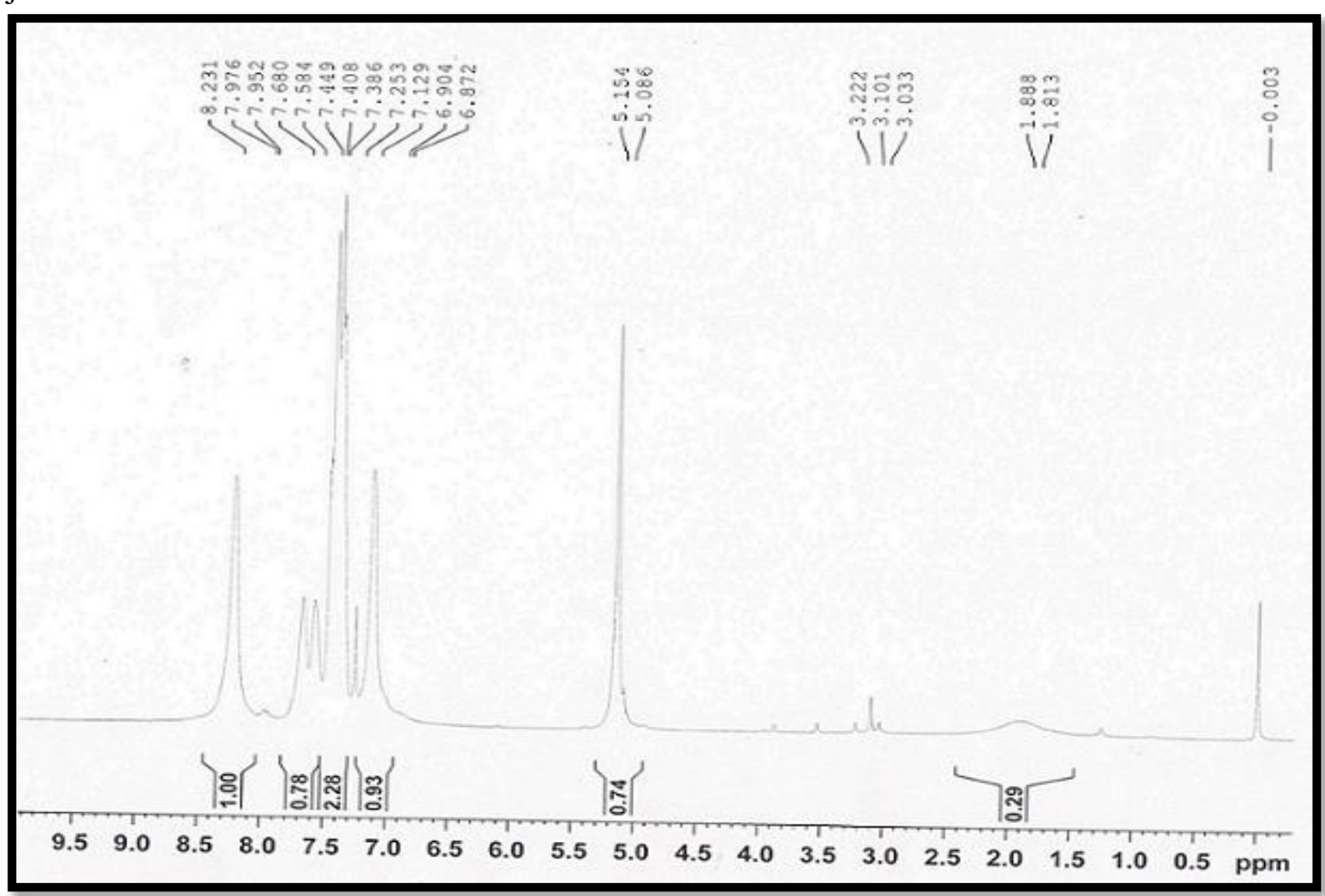


Figure S3. Mass spectra of compounds.

a. M1R

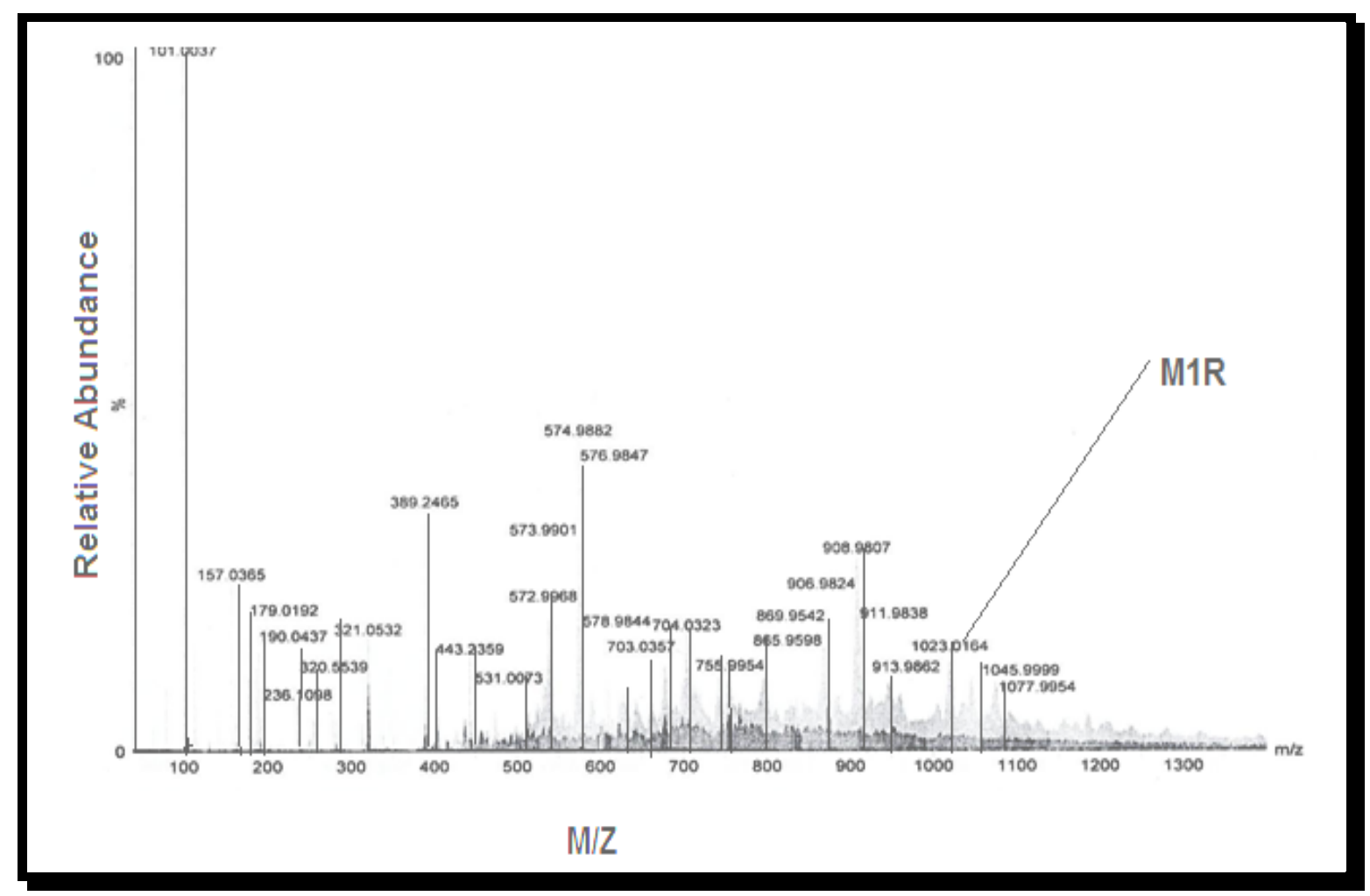

b. M2R

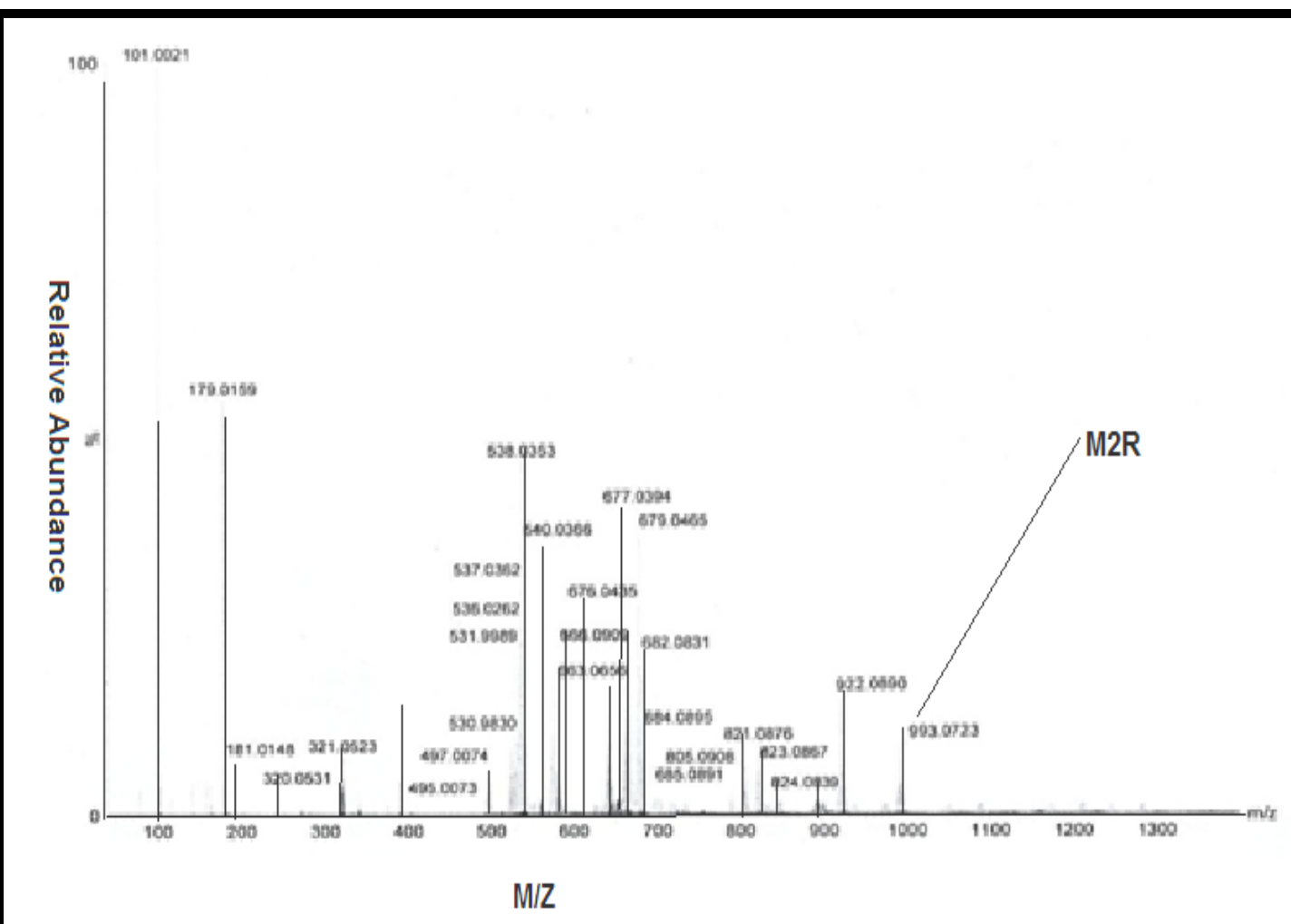




\section{c. M3R}

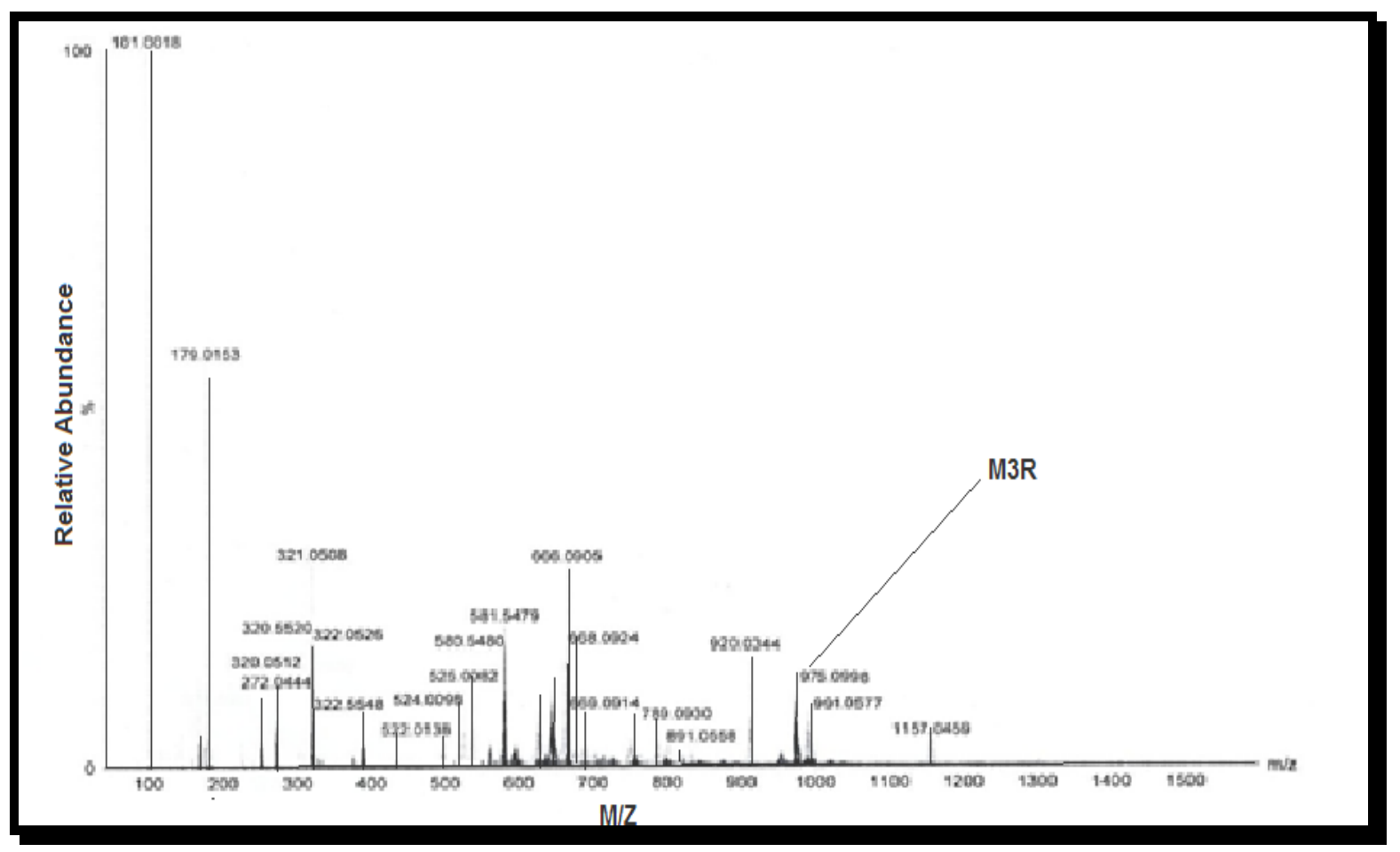

\section{d. M4R}

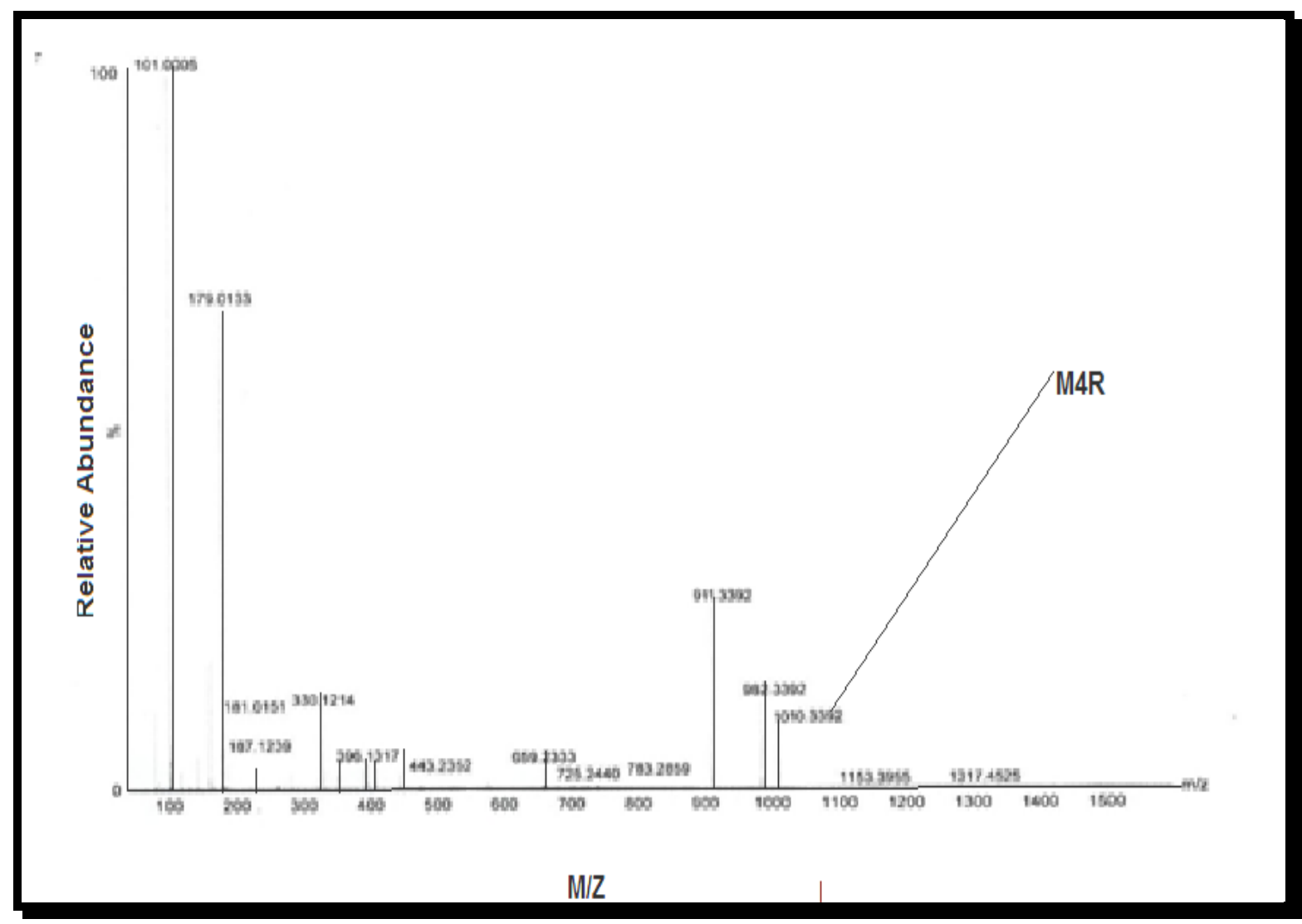




\section{e. $\mathrm{M} 5 \mathrm{R}$}

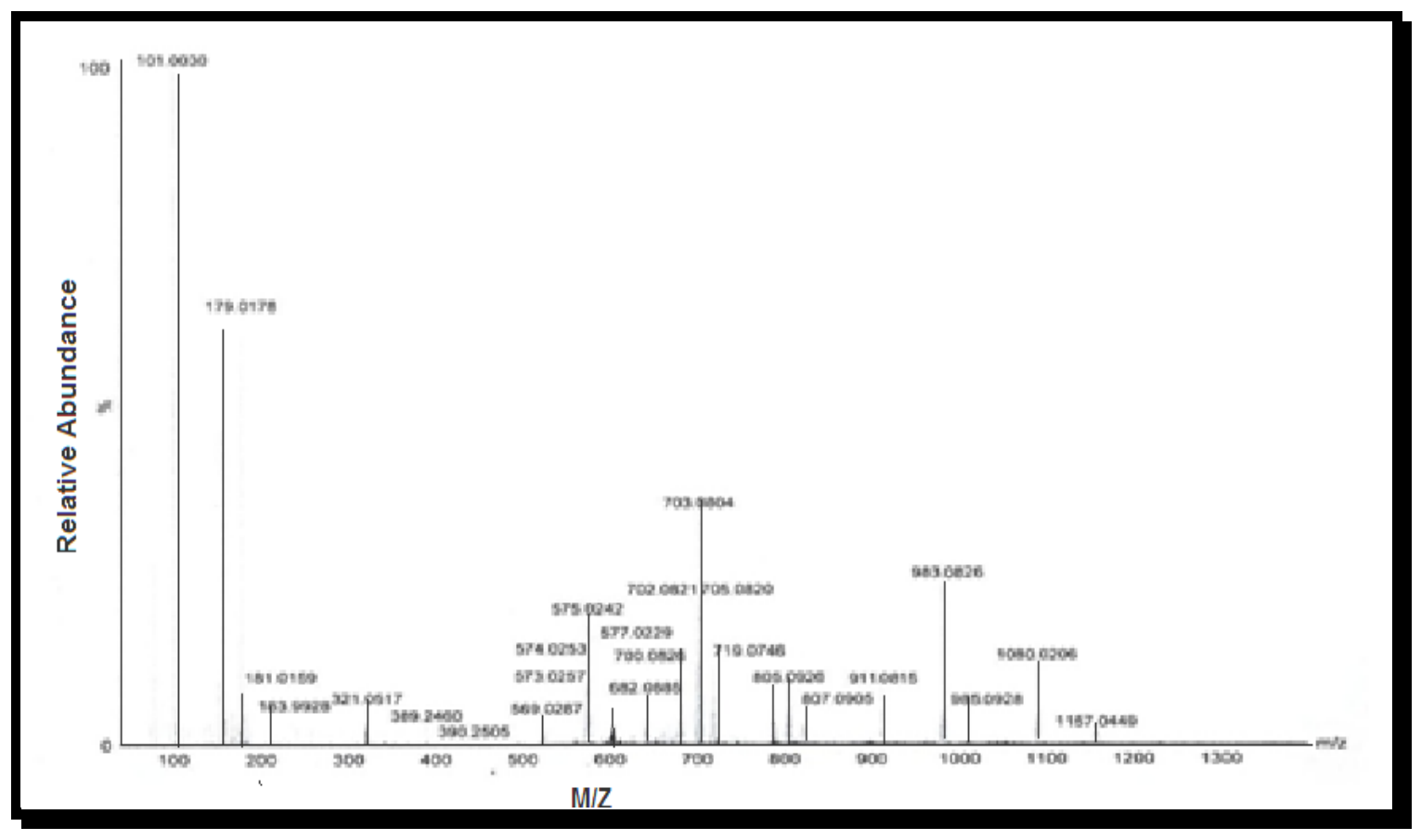

Figure S4. Electronic spectra of compounds.

a. HL1

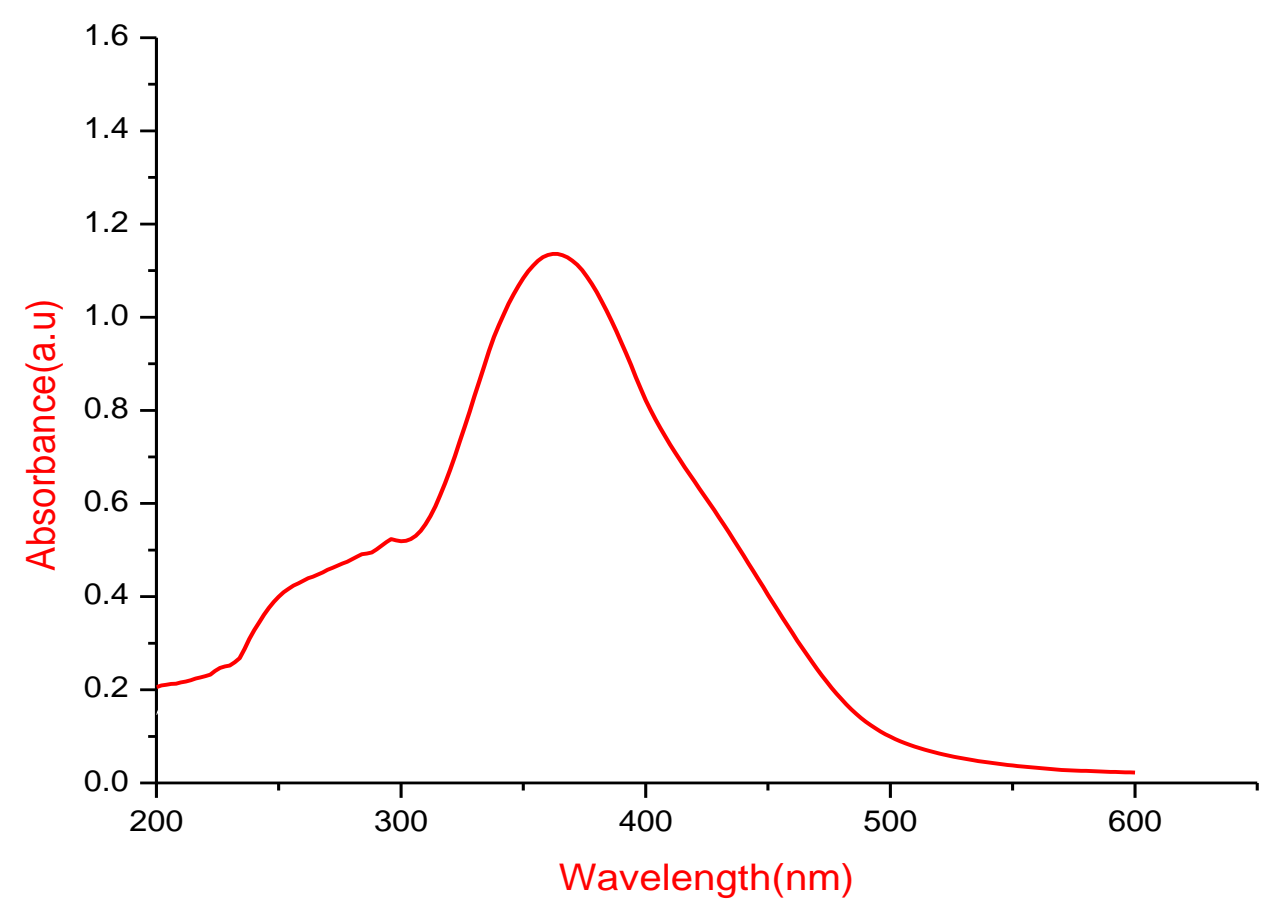


b. M1R

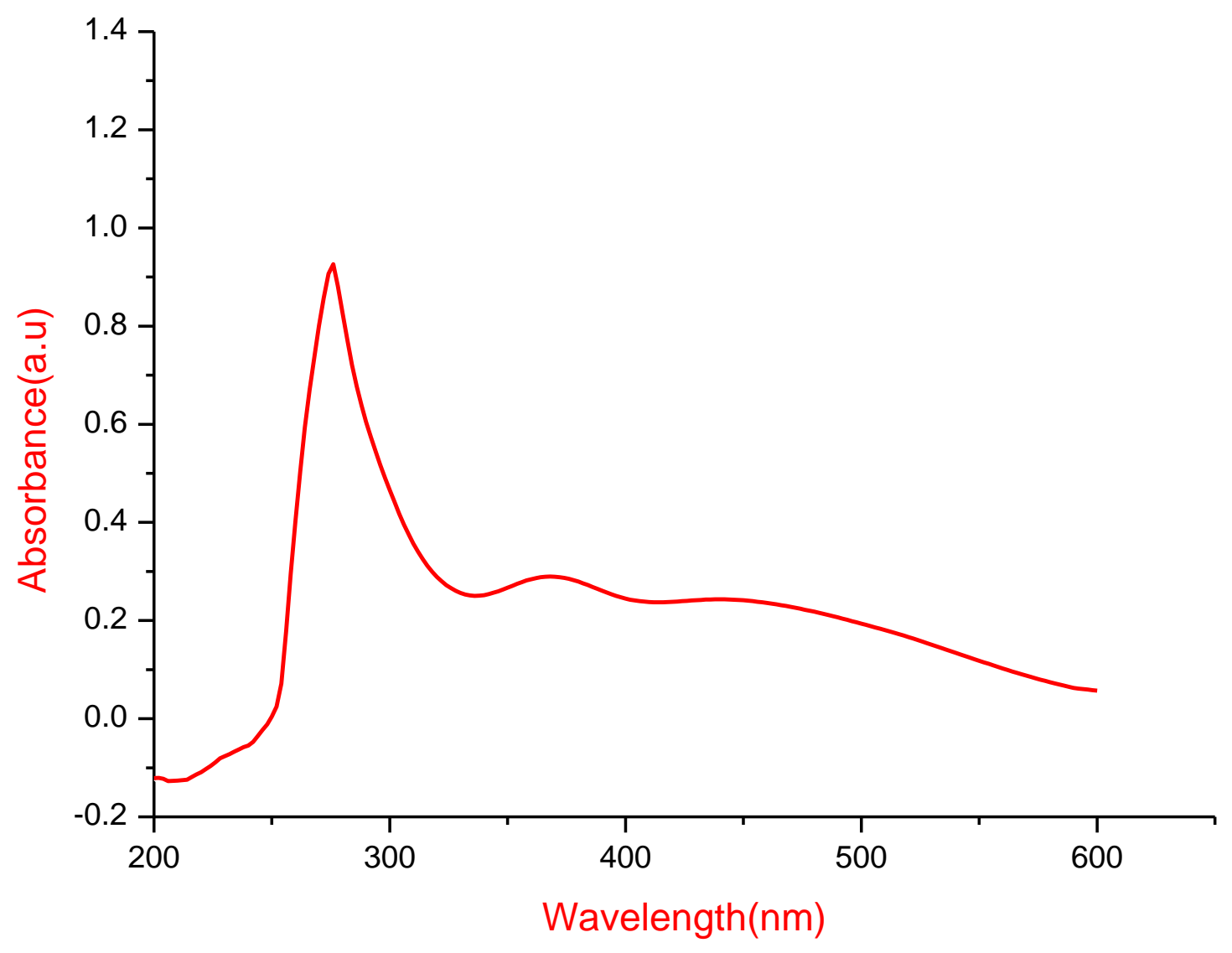

c. HL2

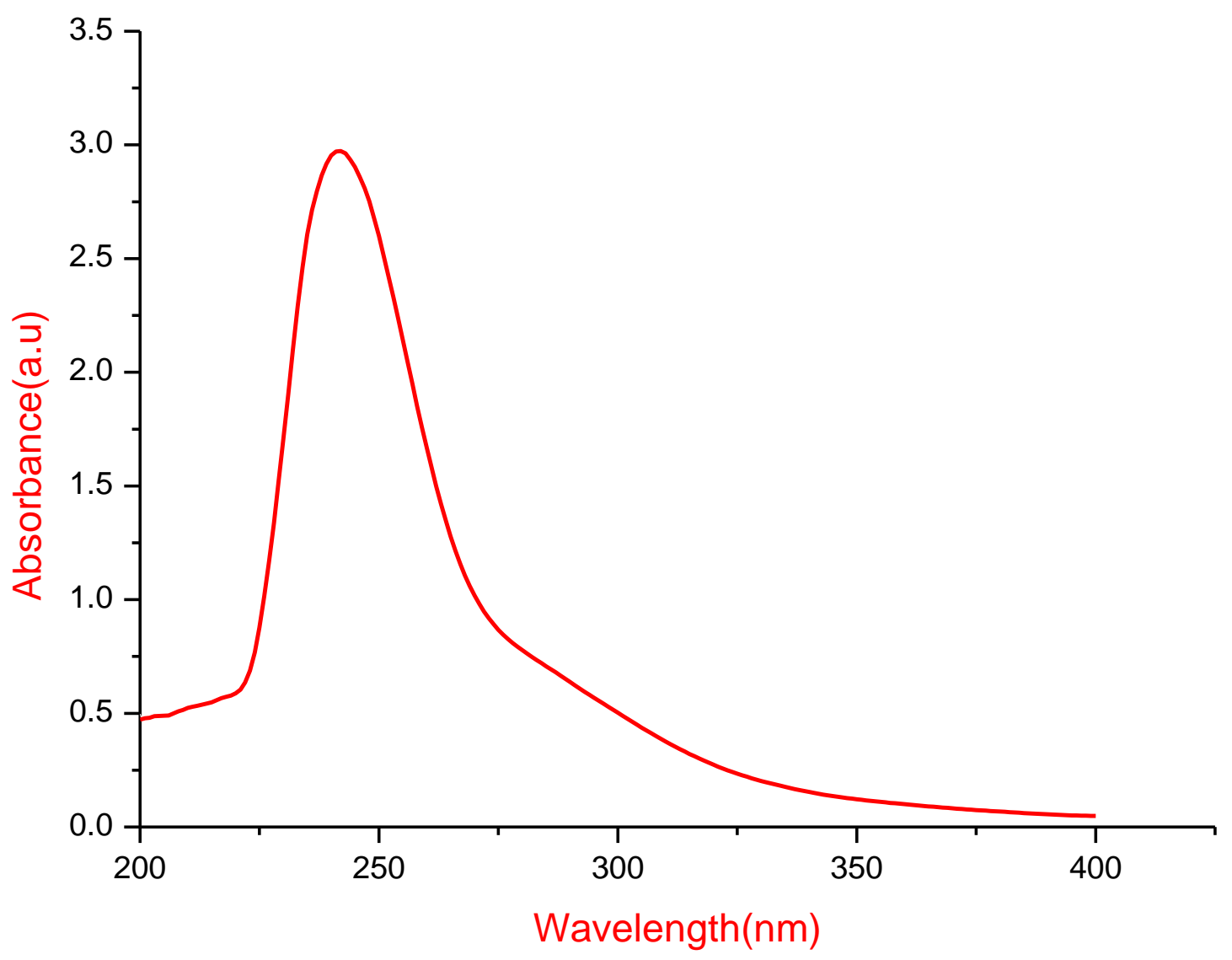


d. M2R

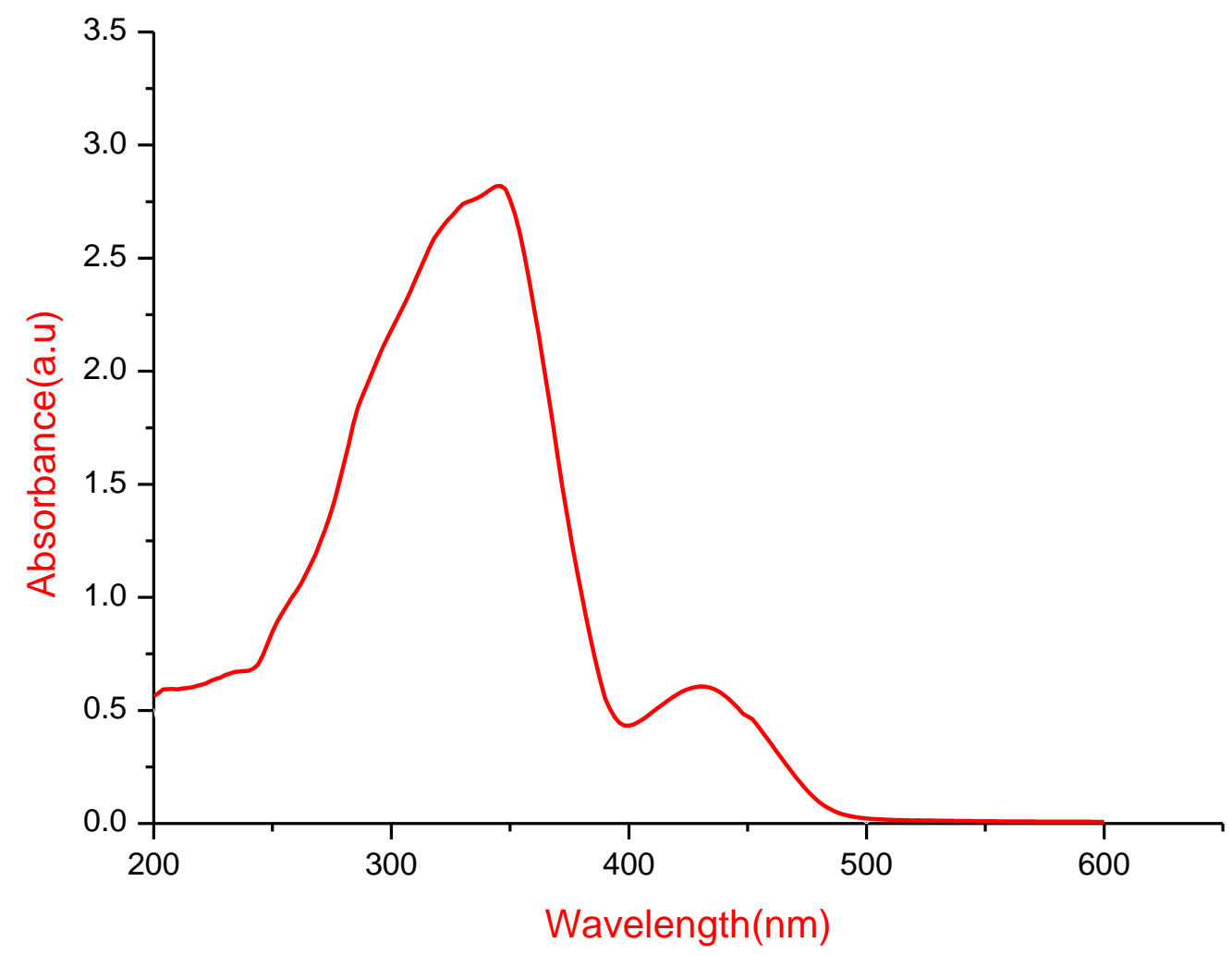

e. HL3

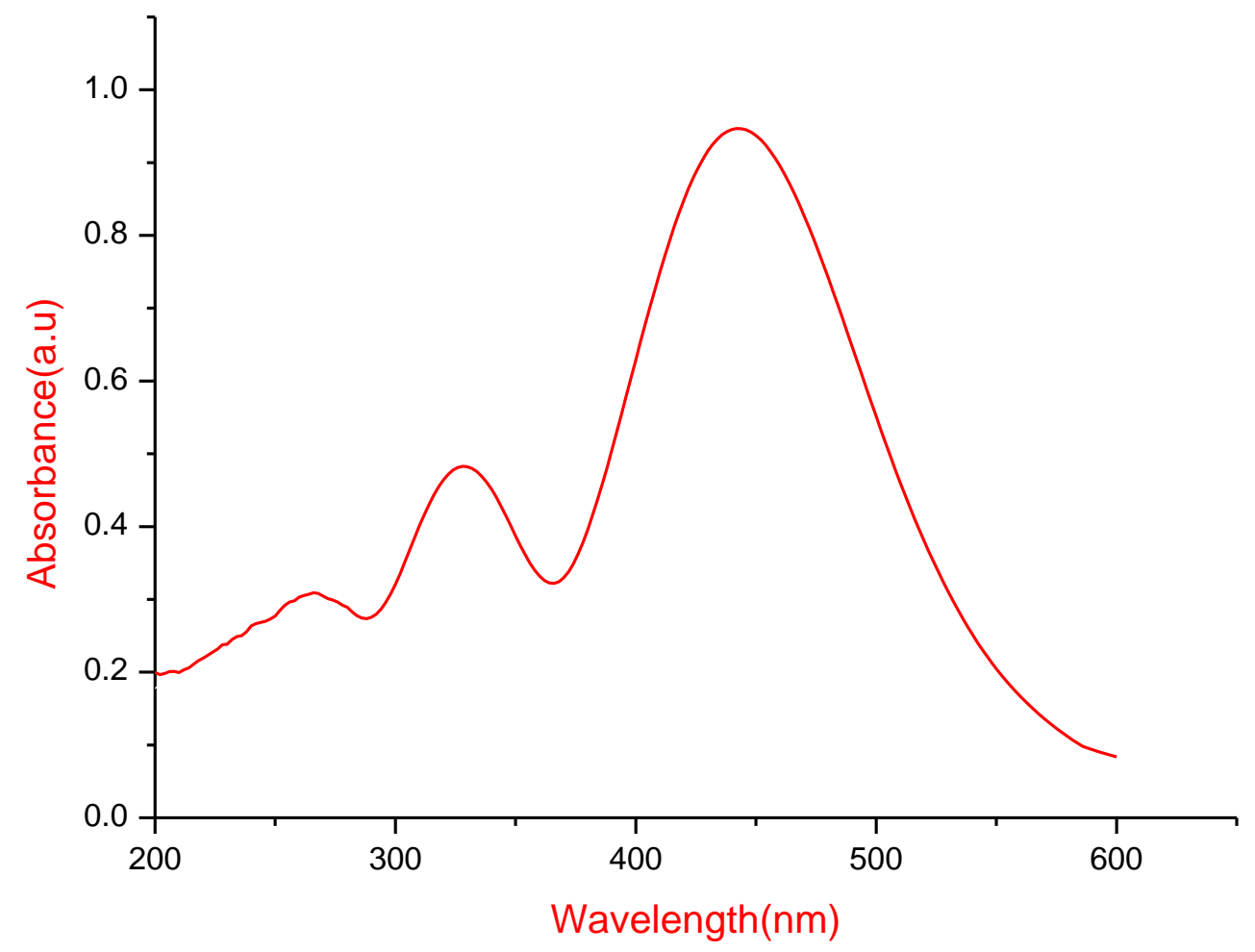




\section{f. M3R}

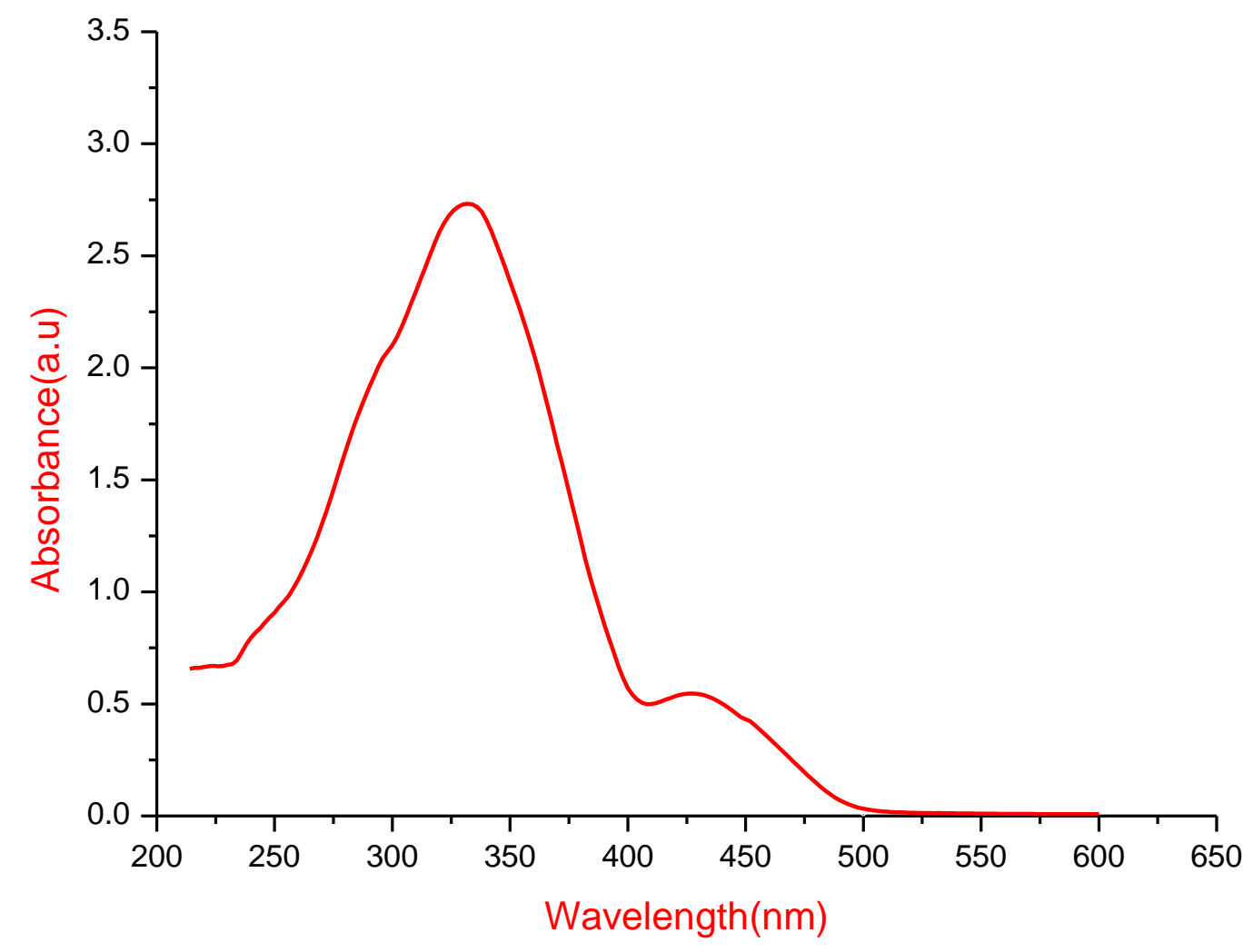

g. HL4

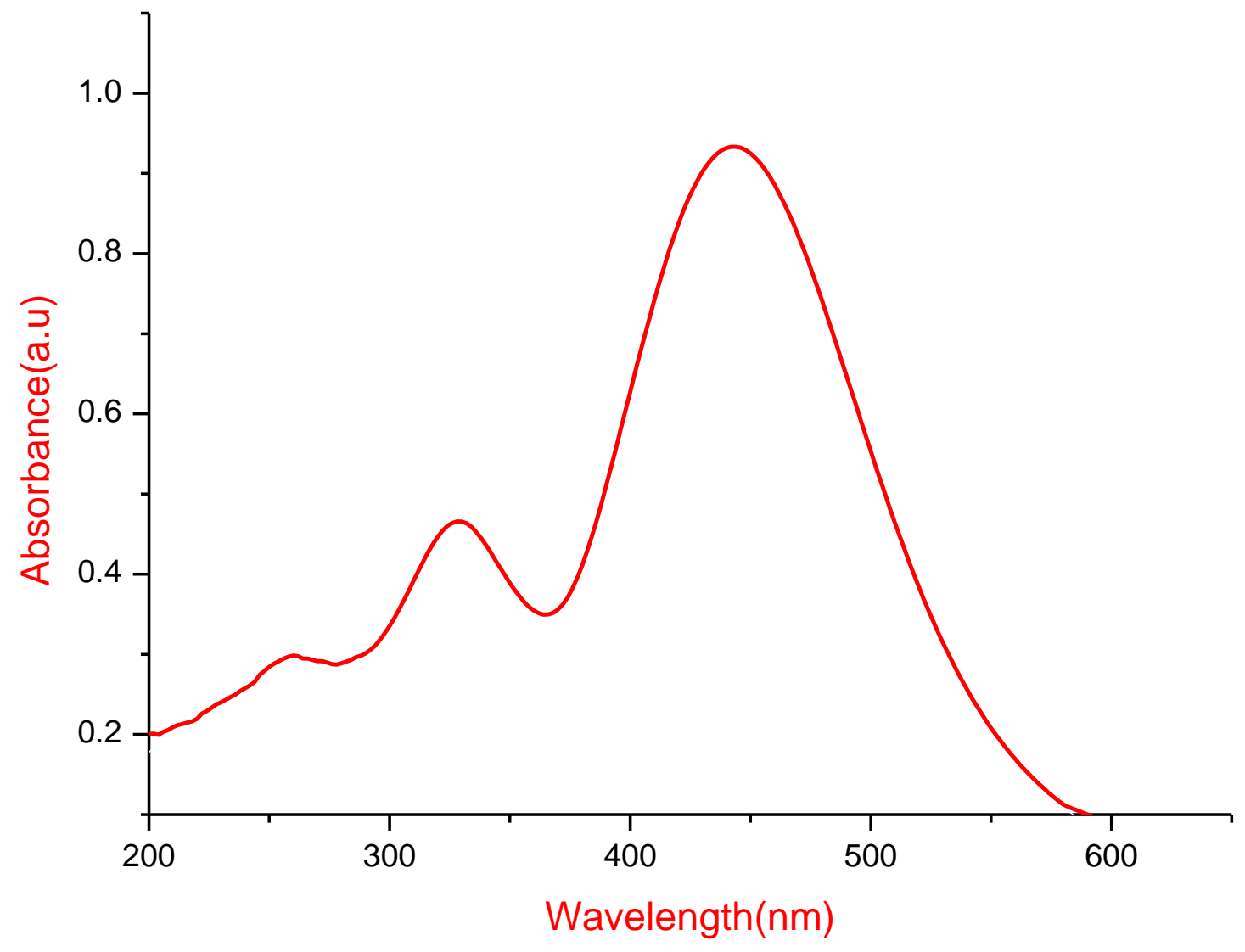


h. M4R

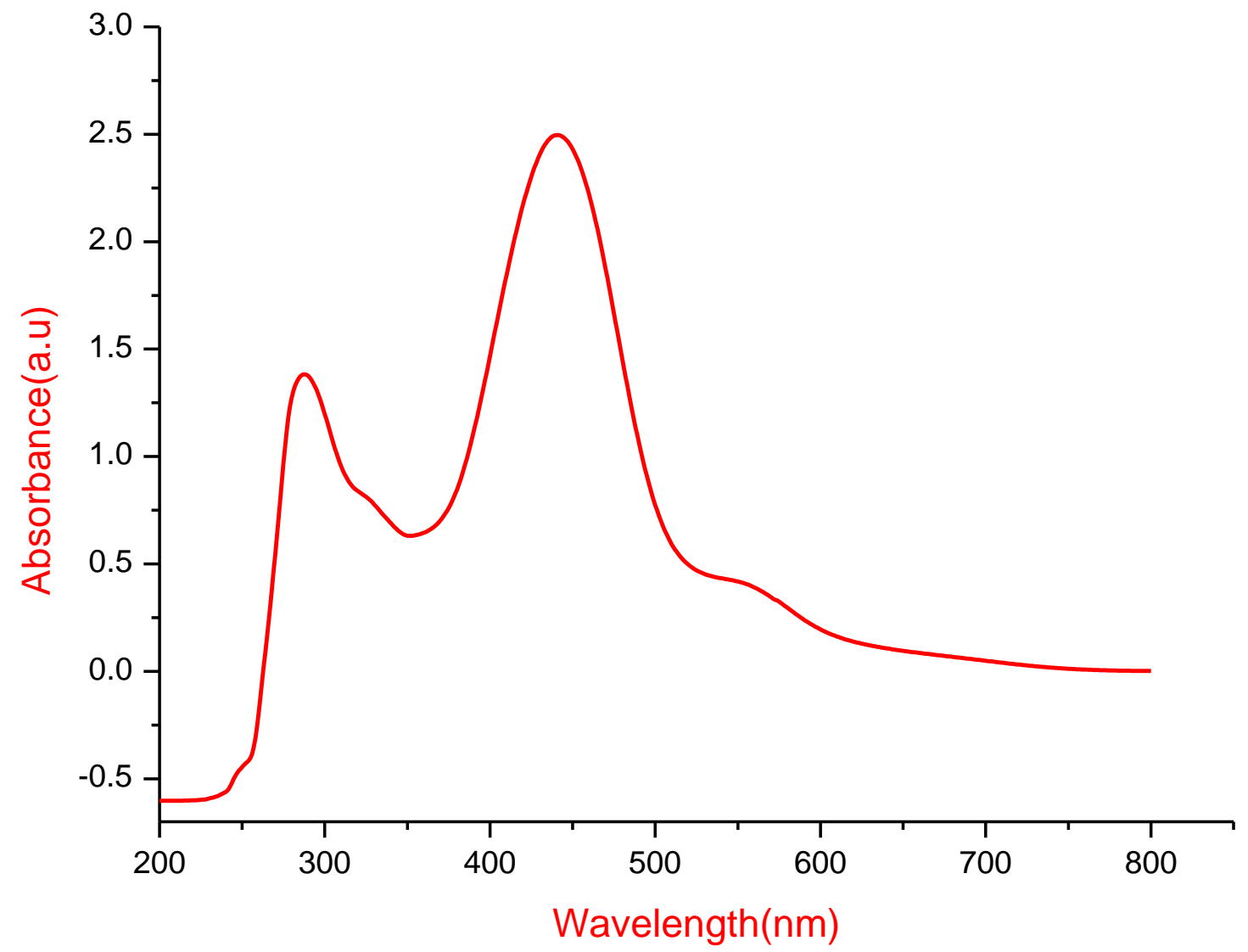

i. HL5

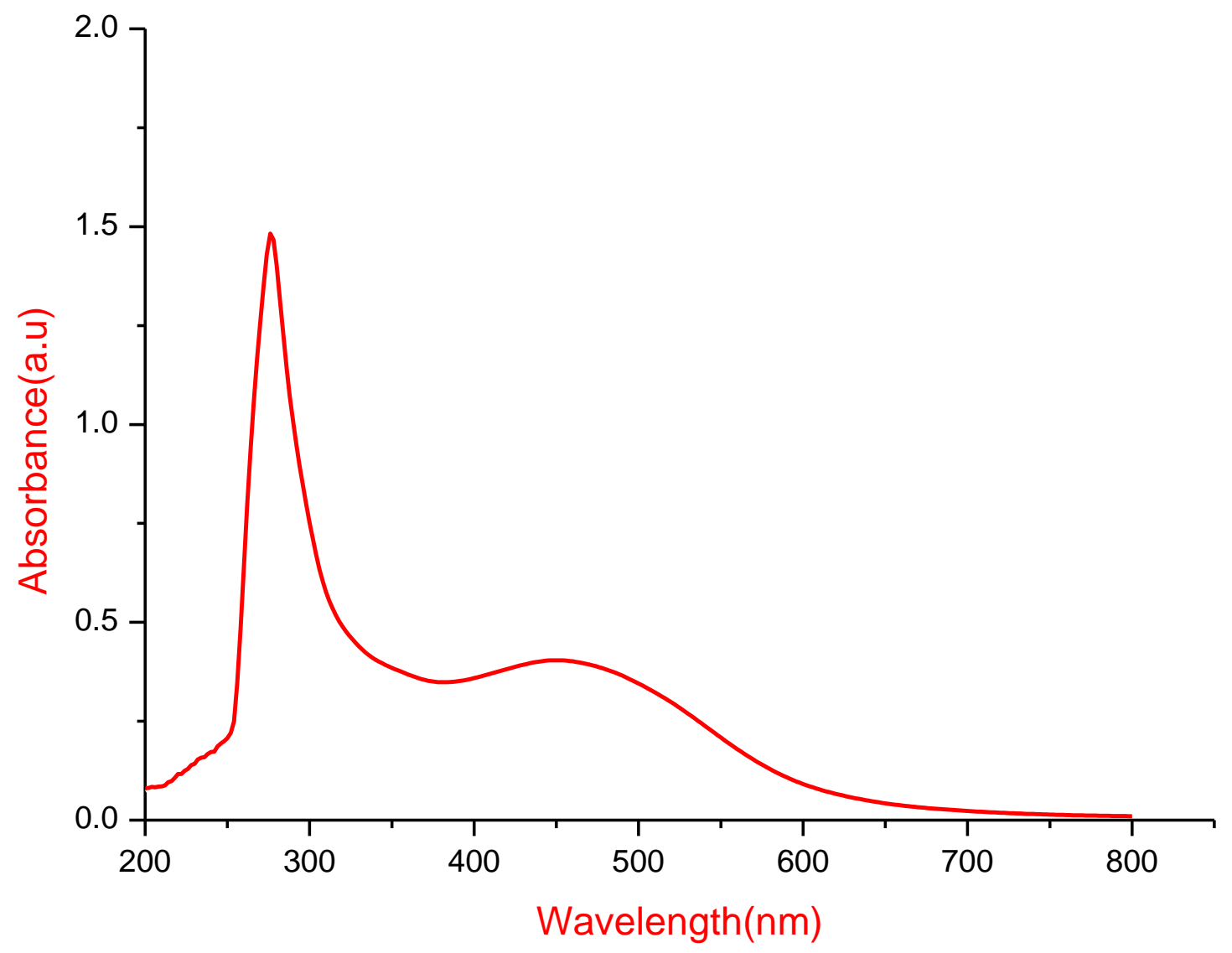




\section{j. $\quad$ M5R}

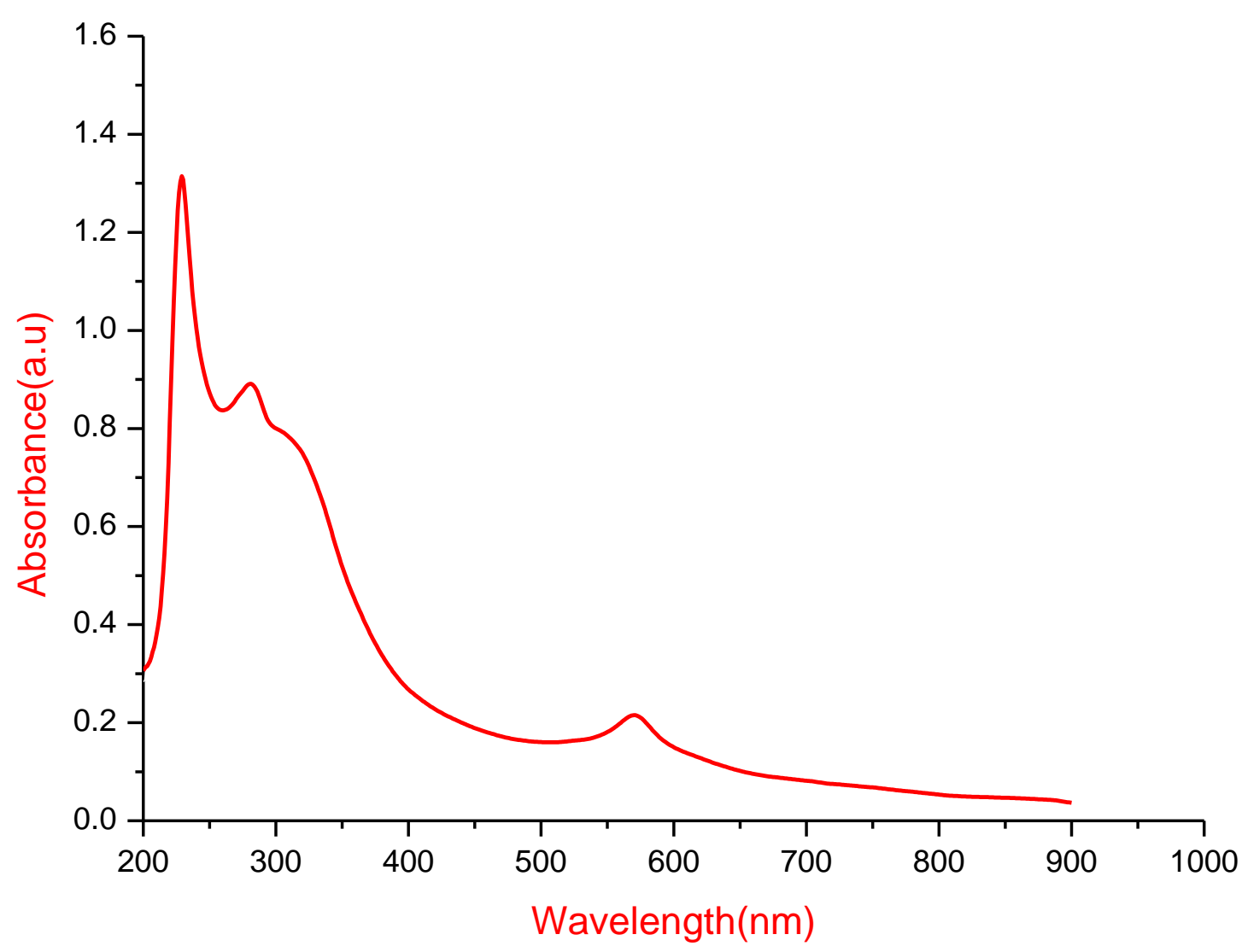

Figure S5. Structure of metal complexes.

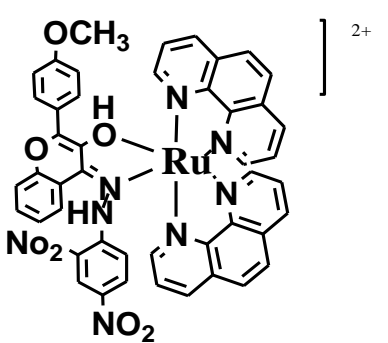

$\left[\mathrm{Ru}(\mathrm{Phen})_{2}(\mathrm{HL} 1)\right] \mathrm{Cl}_{2} \cdot 2.5 \mathrm{H}_{2} \mathrm{O}$ (M1R)

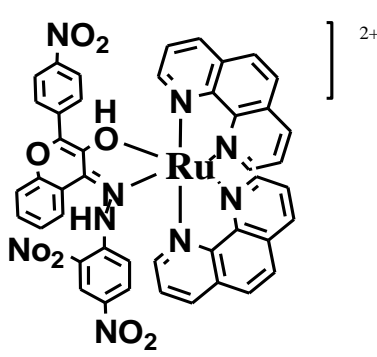

$\left[\mathrm{Ru}(\mathrm{Phen})_{2}(\mathrm{HL} 2)\right] \mathrm{Cl}_{2}$ (M2R)

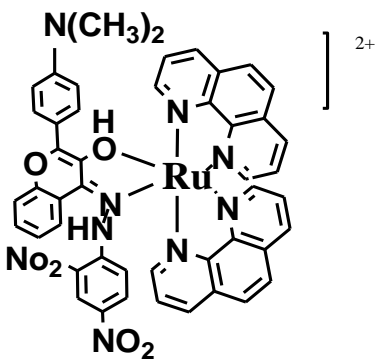

$\left[\mathrm{Ru}(\mathrm{Phen})_{2}(\mathrm{HL} 3)\right] \mathrm{Cl}_{2}$ (M3R)

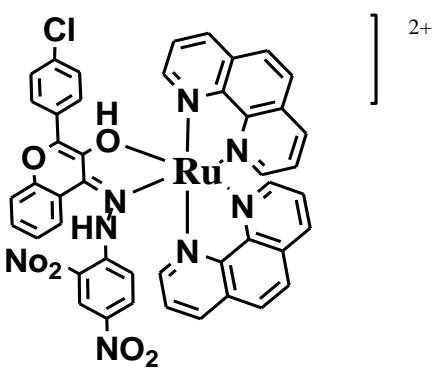

$\left[\mathrm{Ru}(\mathrm{Phen})_{2}(\mathrm{HL} 4)\right] \mathrm{Cl}_{2} \cdot 1.5 \mathrm{H}_{2} \mathrm{O}$

(M4R)

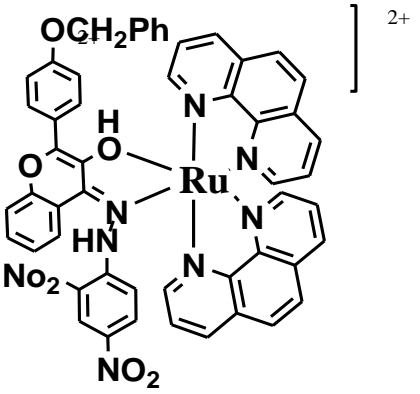

$\left[\mathrm{Ru}(\mathrm{Phen})_{2}(\mathrm{HL} 5)\right] \mathrm{Cl}_{2} \cdot 1.5 \mathrm{H}_{2} \mathrm{O}$

(M5R) 